\title{
Churchyard memorials, 'dispensing with God gradually': Rustication, decline of the Gothic and the emergence of Art Deco in the British Isles.
}

\author{
K.D.M. Snell and Rachael Jones
}

\begin{abstract}
What are the meanings of churchyards and cemeteries and their forms of memorialisation? Such a question preoccupies many today, as in the past. Indeed, we are witnessing in recent times an extraordinary upsurge of public interest in memorialisation, commemoration, and their links to memory. ${ }^{1}$ We wish to describe in this article transitions in English and Welsh churchyard and cemetery memorialisation that have much wider social, artistic and religious significance. The discussion focuses in particular on forms of rusticated memorials that have been entirely neglected by historians and art historians, and how they may shed light on changing attitudes to rurality, 'natural' landscapes and secularisation. As part of an analysis of shifts in memorial taste, we shall consider also the decline of the Gothic - a much neglected topic compared to the earlier Gothic revival - and the emergence of modernist Art Deco styles in memorialisation.
\end{abstract}

There is of course a large historiography on churchyard and cemetery memorialisation, from a number of disciplines. The main attention of that literature has been earlier than our work here: notably looking at memorial style transitions, for example between Death's Head, Cherub, and Willow and Urn types of memorial, or the eighteenthcentury changes from symbols of mortality to immortality, during the largely hand-crafted eras of churchyard memorial creation. Such scholarship especially discussed the artistic,

We are grateful to Richard Butler, Carl Griffin, Stuart Stanton, Rosemary Sweet, Tom Williamson, and Rural History referees for their valuable comments and suggestions.

${ }^{1}$ This development is stressed in C.J. Griffin and B. McDonagh (eds), Remembering Protest in Britain since 1500: Memory, Materiality and Landscape (Basingstoke, 2018), Introduction. 
theological, social, regional and international significances of memorialisation. ${ }^{2}$ This article develops that historical and archaeological research, notably into a later post-1850 period and to different themes that have often been ignored by researchers. It covers a range of issues notably 'rustication', the decline of the Gothic, the emergence of Art Deco - that are much later than the problems of, for example, why images of mortality gave way to symbols of immortality, or why a stark language of mortal remains was supplanted between $c$. 17501850 by one of affectionate familial remembrance. Rustication as a theme has slipped through the trees in this earlier research, a situation that we hope to redress here, considering it within the framing of the two more dominant styles (Gothic and Art Deco) that chronologically abutted it. As in all such work, we need initially to remind ourselves that before the twentieth-century inter-war period we are dealing largely with the gravestoneleaving classes - the upper and middle classes - and that such memorialisation was then usually a minority and relatively costly phenomenon. It was only subsequently that stone memorials became much more numerous and widespread socially, and we shall return to this issue.

'Rustication' has very long-standing meaning in architectural history, across multiple contexts, yet is widely missed in the genre of memorials. ${ }^{3}$ The subject has wide potential interest for rural historians. It means in this discussion the deployment of rough stone imitation or natural stone, sometimes with naturalistic timber or tree effects in stone, to create an impression of textured solidity, strength, roughness, irregular and uneven naturalism. This

\footnotetext{
${ }^{2}$ An enormous literature is relevant, but see in particular F. Burgess, English Churchyard Memorials (1963, London, 1979); J.S. Curl, The Victorian Celebration of Death (Newton Abbot, 1972); P. Aries, Western Attitudes to Death from the Middle Ages to the Present (London, 1974); J. Deetz, In Small Things Forgotten: the Archaeology of Early American Life (New York, 1977); N. Llewellyn, The Art of Death: Visual Culture in the English Death Ritual, c. 1500-1800 (London, 1991); S. Tarlow, Bereavement and Commemoration: an Archaeology of Mortality (Oxford, 1999).

${ }^{3}$ Among very brief mentions, see Burgess, English Churchyard Memorials, pp. 126-7, 139, 202. This remains the finest book on the pre-1850 genre, though he appears to dislike almost all subsequent developments. We do not share his critical attitude towards rusticated memorials - as 'foreign', asymmetrical, 'made to ape rustic work' - which prevented him from seeing their significance.
} 
rough, rock or arboreal facing may involve recessed joints to create shadows. ${ }^{4}$ With attention to memorials, we use a definition such as that given by Betty Willsher: 'Rustication is a method of treating the surface of the stone, producing an effect like a rocky surface, or like wood in the shape of logs...The stones may be embellished with doves, crosses, anchors, ivy or flowers'. ${ }^{5}$ Rustication takes many forms in architecture and monuments. It had ancient and Classical usage, and was popular in revived styles of Italian renaissance architecture, notably for the lower parts of buildings. It was sometimes used by architects to copy the effects of antique ruins. It may involve 'picked' work, which means chiselling of stone to create a rough surface effect. 'Vermicular rustication' is the deliberate imitation of patterns left by worms in sand, mud or wood, and this is a widely seen architectural style, though less often found for churchyard memorials. ${ }^{6}$ 'Frost work' rustication refers to the imitation of icicles and stalactites, which is very rare in memorialisation. Linked more to garden design, 'cyclopian rustication' refers to where the stone blocks are large and irregular, monolith-like as if placed by giants, while 'rock-work' rustication is akin to a randomised pile of rocks, which is also found in follies, rockeries, fountains, water cascades and so on. ${ }^{7}$ Such forms may also be imitated in other materials than stone, ${ }^{8}$ as for example in stucco, plaster, cement, wood, bricks, modern fibre-glass constructions over frames (notably in some game parks or

\footnotetext{
${ }^{4}$ See https://en.wikipedia.org/wiki/Rustication_(architecture) (24.1.2018), for examples. In our analysis of rusticated memorials we have discounted smooth-faced and regularly shaped stone with recessed joints, occasionally found in the base of larger monuments, and conventionally included by architectural historians in definitions of rustication. For further terminology and definitions, see J. Summerson, The Classical Language of Architecture (London, 1996); J.S. Curl, A Dictionary of Architecture (Oxford, 1999); J.S. Curl, Classical Architecture: an Introduction to its Vocabulary and Essentials (London, 1992); J. Fleming, H. Honour and N. Pevsner, The Penguin Dictionary of Architecture (Harmondsworth, 1991).

${ }^{5}$ B. Willsher, Understanding Scottish Graveyards: an Interpretative Approach (Edinburgh, 1985), p. 23.
}

${ }^{6}$ A. Clifton-Taylor and A.S. Ireson, English Stone Building (London, 1983), pp. 114-5.

7 'Bossage', the use of sharply pointed or raised decorated or patterned masonry - a late Gothic form sometimes termed Isabelline Gothic - is not really a feature of rusticated memorials and will not be covered or included here.

${ }^{8}$ A. Clifton-Taylor, The Pattern of English Building (London, 1972), pp. 41, 47-8. 
zoos), and so on, though these rarely feature in external memorialisation in churchyards and cemeteries.

As a style of memorialisation, rustication suggests 'rustic' and 'Natural' references or equivalences. It can even hint artistically at the Sublime. Natural stone or tree/wood forms are frequently imitated in churchyard and cemetery memorials. In some cases, these elements are both combined in the same memorial. Thus one can see imitative wood and stone combinations which we will refer to as 'dual' forms of rusticated memorial. With such rustication, an element of rustic or rocky simplicity, aspiration or sympathy was often aimed for. Of course, one also finds countless examples of naturalistic flower and plant imitation carved on memorials for all periods, following different and shifting fashions, folklores, folk art and symbolism: a plethora of flowers, acanthus leaves, palm fronds, tree or cropped-tree illustration, and so on, referencing a wider culture and language of flowers, trees, and their meanings. ${ }^{9}$ But these important design elements are not conventionally described as rusticated memorials and are not included in our analyses here, even though their shifting and regional emphases comprise a fascinating field for analysis. Such floral or arboreal design elements are different from memorial rustication, as the latter takes the form of, or is largely dominated by, a key element of naturalistic stone or tree life, rather than being a memorial on which has been inscribed or carved smaller elements of plant or arboreal life.

Important questions arise when we consider these forms of rusticated memorialisation and related artistic taste. What does such rustication tell us about attitudes to the natural world? ${ }^{10}$ How and where were these styles used in memorials; and when did they most

\footnotetext{
${ }^{9}$ On the wider issues here, see J. Goody, The Culture of Flowers (Cambridge, 1993); B. Seaton, The Language of Flowers: A History (Charlottesville, 1995); E. and J. Lehner, Folklore and Symbolism of Flowers, Plants and Trees (New York, 1960). M. Engelhardt, 'The language of flowers in the Victorian knowledge age', Victoriographies, 3:2 (2013), pp. 136-160; B. Elliott, The Victorian Language of Flowers, Occasional Paper from the RHS Lindley Library, 10 (April, 2013), pp. 3-94; Burgess, English Churchyard Memorials, pp. 179-81, 184-6, 194, 202-6, 222, 234-5, 251; J. C. Davies, 'The 'tulip slates' of south Leicestershire and north-west Northamptonshire', The Leicestershire Historian, 4:1 (1993); F. Greenoak and C. Roberts, Wildlife in the Churchyard: The Plants and Animals of God's Acre (1985, London, 1993).
}

${ }^{10}$ The key book here is K. Thomas, Man and the Natural World: Changing Attitudes in England, 1500-1800 (London 1983). Thomas' excellent book may have missed an opportunity by not including memorials in its analysis. 
feature? What do they suggest about the relation between religious forms - whether Anglican, Catholic or Nonconformist - and empathies with Nature, and how did those religious forms, cosmologies or organisations influence the types of rustication? Were the latter more prominent in churchyards, or more secular cemeteries? Given prior traditions of memorialisation, with their strongly religious themes, is rustication a complex index of, or pointer to, 'secularisation', and is it expressive of social trends and ways of thinking that were less 'religious' in nature? What were the wider artistic and social meanings of memorial rustication, and is this linked to the arts and crafts movement, or to the 'back to the land' movement, broadly defined ${ }^{11}$ Are rusticated memorials indicative of certain attitudes to the countryside? How regional was their uptake, and did Celtic regions adopt them at the same time as English metropolitan areas? What is the regional chronology of this development, and what may that tell us about regional fashion change in the metropolis and the so-called provinces? Is rustication a rural or urban memorial form, or was it indifferent to town and countryside differences? Were such memorials influenced by local availability of types of stone which might lend themselves to rustication? How did rustication merge with or relate to other memorial forms, whether in chronology, stylistic influence, or artistic difference: the memorial styles most notable here were the Gothic and Art Deco. What residual forms does rustication have now, and why?

Rustication in architecture was also sometimes used to demarcate or suggest class or social divisions. This is sometimes found in the external layering of stone work in great houses, especially in the eighteenth-century Palladian revival, where the servants' or service quarters could lie behind the lower rusticated level of stonework, seeming to serve also as a solid and rougher foundation, while more 'polite' owners' floors of residence usually lay behind the smoother more 'finished' ashlar stonework above. This was so, to take a neoclassical example, with the 'rustic floor' of Kedleston Hall (Derbyshire). ${ }^{12}$ Hence one needs to bear in mind that rustication in church or cemetery memorialisation may hint at political or social empathies, whether personal or fashion-based, as well as at certain empathies with

\footnotetext{
${ }^{11}$ J. Marsh, Back to the Land: the Pastoral Impulse in England, 1880-1914 (London, 1982).

${ }^{12}$ For other architectural examples, like Sandbeck Hall (Yorks.), see Clifton-Taylor, Pattern of English Building, pp. 47-8; Clifton-Taylor and Ireson, English Stone Building, pp. 113-5; S. Hart, Flint Architecture of East Anglia (London, 2000), p. 17 (Holkham Triumphal Arch).
} 
Nature or sympathies with the natural world. Such memorials may also be a taste-related extension of elements of architectural history, depending upon the styles of rustication deployed.

\section{The monolith}

Pictorial examples are needed here to indicate the various forms that rusticated memorials take. It is appropriate to start with the 'monolith'-type memorial, where the 'rustic' or naturalistic element was most obviously pronounced. ${ }^{13}$ This type of memorial may be found in many periods, and often featured in regions where the dominant stone types were relatively resistant to fine carving, for example granite, or where an abundance of rough stone was available, or where masonry skills were limited locally, or where its relatively low cost made it useful as a memorial. Monolith memorialisation is common for example in the Aran Islands off Galway, or in parts of the Scottish Highlands, or in the Charnwood parishes of Leicestershire. Conversely, despite the massive availability of local stone, it is rare in the Isle of Portland, because of the exceptionally high quality of limestone there and the skills of local quarrymen and carvers. In some cases the potential cheapness of such memorials can mark persons less pertaining to the locality, or of a lower class, standing instead of a more carefully prepared and expensive memorial. A 1970 example (see Figure 1) from Inisheer, one of the Aran Islands off Galway, to Orla Knudson [sic], simply says in Gaelic: 'Cuimnig ar "An Dane"” (trans: 'Put remembrance on The Dane', or 'Remember The Dane'). It commemorates an 'outsider', Orla the Dane (Orla Knudsen), a self-taught weaver living in a very small house who worked a loom built from driftwood. ${ }^{14}$

\footnotetext{
${ }^{13}$ See the figurative example in H. Mytum, Recording and Analysing Graveyards (York, 2000), pp. 112-3, n. 8400 in his classification.

${ }^{14}$ We are grateful to Richard Butler for translation. On Orla Knudsen, see C. Bird and K. Rafter, This is Charlie Bird (Dublin, 2006).
} 


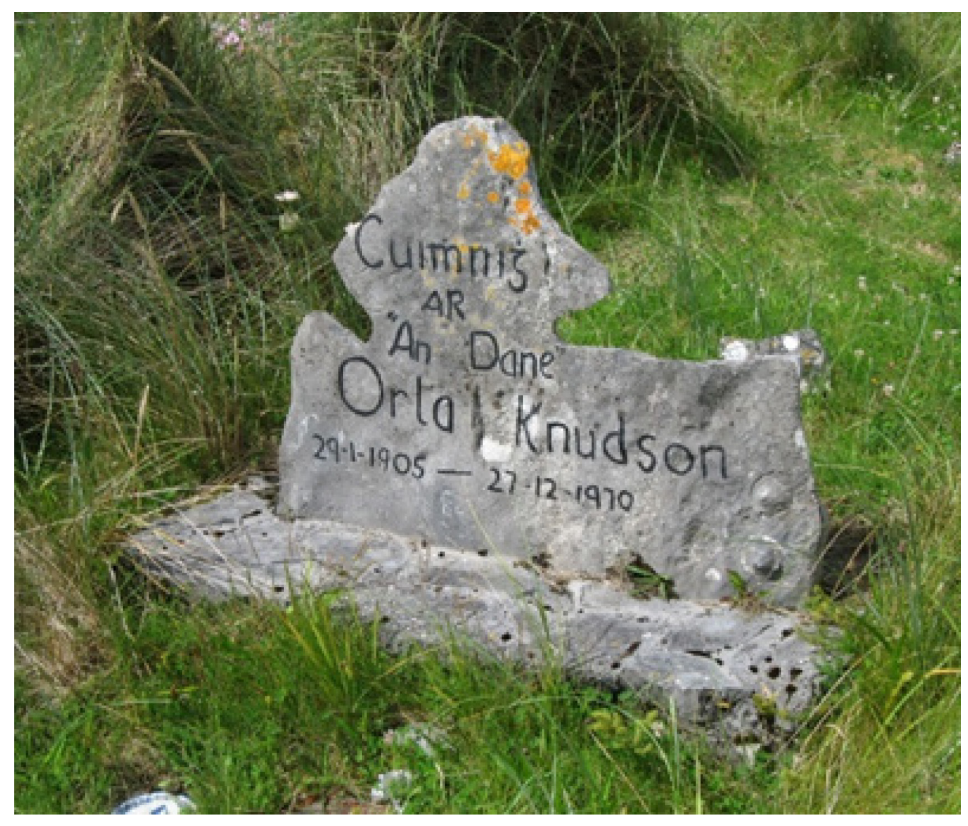

Figure 1: Inisheer, Aran Islands. 'Cuimnig ar “An Dane”, Orla Knudson', 1905-1970.

It is worth stressing how enduring (both as material and fashion) these memorials are, for while they can be found throughout the British Isles in the medieval and early modern periods, or as a rare, inexpensive and less class-impressive form in the eighteenth and nineteenth centuries, they are also a type of memorial that came back into popularity from the later nineteenth century, and then (as we shall see) again in recent decades. Such monolith memorials mark some recent burials, including in village and urban cemeteries. They traverse periods and regions, but more recently are a fascinating revived form.

Monolith types may also act as a collective memorial, as in the Irish rusticated memorial (and increasing cairn), dated 1849, which commemorates victims of the Irish Famine 1845-9 in Doolough in south-west County Mayo. Indeed, it is also the case that ruins may act as memorials, as one finds notably in Ireland and Scotland. ${ }^{15}$ Or there was the First World War memorial referred to in the Parish Meeting Minutes of Newbold Verdon (Leicestershire) in 1924: 'a rough granite stone large enough to inscribe the names of the

15 I.J. McPherson Robertson, 'Hardscrabble Heritage: the ruined blackhouse and crofting landscape as heritage from below', Landscape Research, 40:8 (2015). Such identification is not rustication as used here but it does speak to interesting parallel processes with regard to the rustic. 
fallen' ${ }^{16}$ A more individualised example is seen in Figure 2, for a one-month old infant, Colin Logan, memorialised in 1888 in the churchyard of Church Langton, Leicestershire. Here it might appear that the 'inchoate', simple or unspoilt memorial denotes an undeveloped life, as if sculpturally prepared yet never completed.

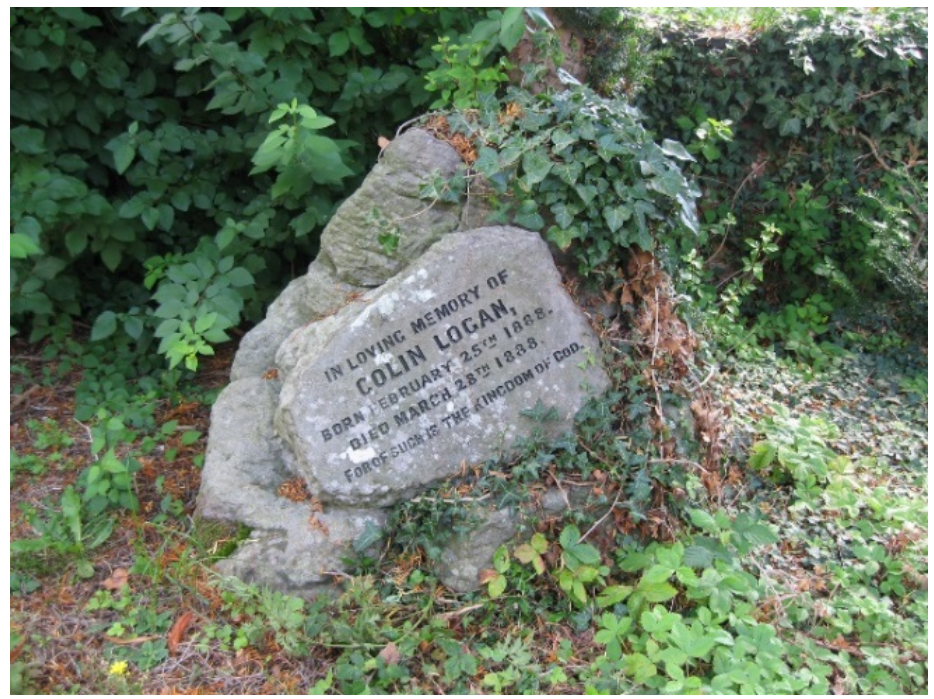

Figure 2. Church Langton churchyard, Leicestershire. Memorial to Colin Logan (Feb. 1888 - Mar. 1888).

The nature of these monolith-type memorials varies considerably, exploiting the shapes of the natural stone, and its symbolic possibilities. Another moving example, see in Figure 3, from Hallaton village cemetery in Leicestershire, combines monolith rustication with a deliberately shaped symbol of the cause of death. This occurred through the accidental fall by 29 year old Dr Iain Challoner-Courtney and his American fiancée Dr Wendy Havelka from the Jungfrau in the Swiss Alps in July 1994, shortly after becoming engaged. The rustic memorial quite accurately represents the shape of the mountain. 'They died together on the mountains they loved', reads the monolith's inscription. An article in The Times describes their being roped together and falling 2,500 feet while descending after having reached the

\footnotetext{
${ }^{16}$ Parish Meeting Minutes, Newbold Verdon (Leics.), Record Office for Leicestershire, Leicester and Rutland, DE 3155/4 (25 March, 1924). Rough stone rustication is a common feature for war memorials: see for modern examples A. Borg, War Memorials from Antiquity to the Present (London, 1991), plates 92, 136, 148, 160, 171, 173, 174, 177.
} 
mountain's summit. ${ }^{17}$ One notices here also a high level of educational attainment and a love of Nature associated with a rusticated memorial, a theme to which we shall return.

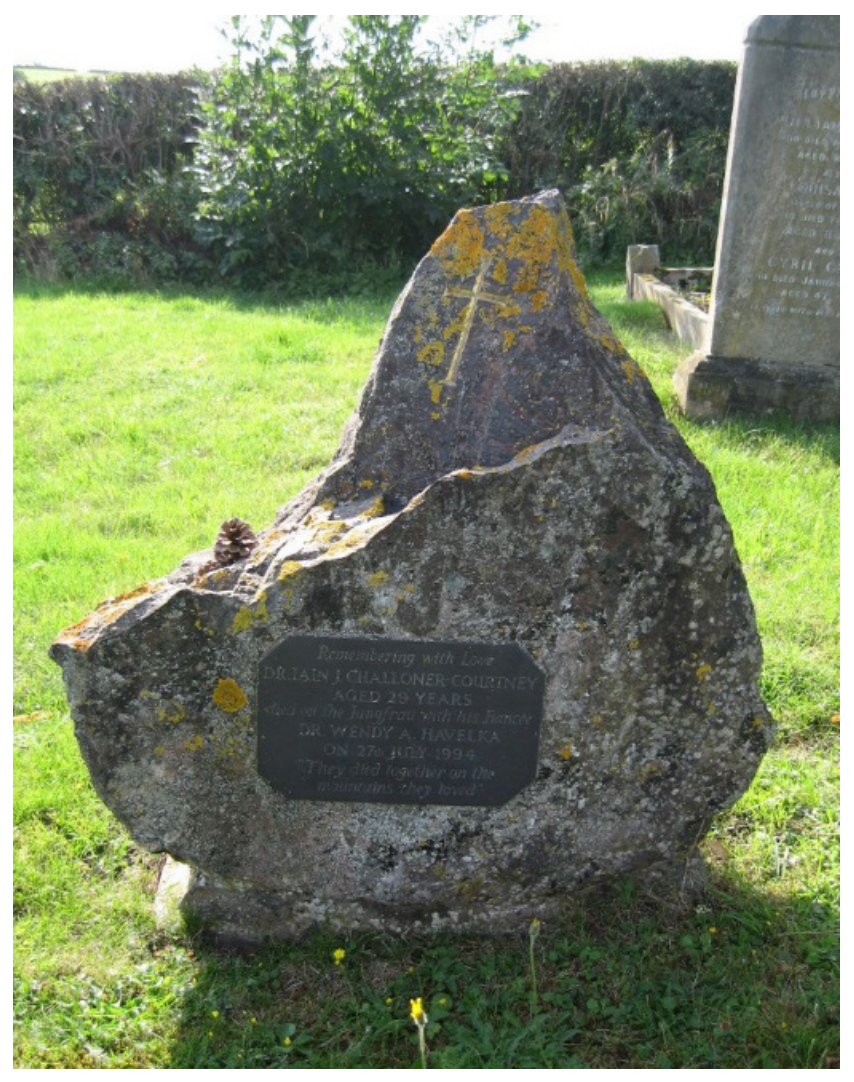

Figure 3. Hallaton cemetery, Leicestershire. Memorial to Dr Iain J. ChallonerCourtney (aged 29), who died on the Jungfrau with his fiancée Dr Wendy A. Havelka on 27 July, 1994.

In some other such cases of monolith or rustication themes, aspects of the person or his/her occupation were apparently being referenced by this medium. A 1928 example from Northampton, perhaps of a blacksmith, is shown in Figure 4, for John Edmund and his wife Elizabeth, the rustication of which may also relate to hardiness of occupation, character or physique.

\footnotetext{
${ }^{17}$ A Staff Reporter. 'Couple died roped together after fall from alpine peak,' The Times, 19 Jan., 1995, p. 3.
} 


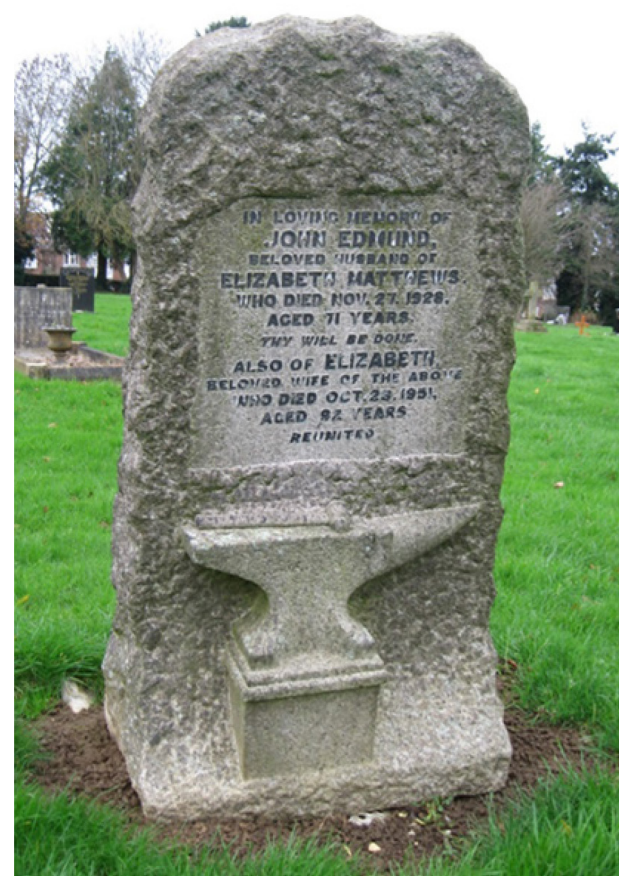

Figure 4. Towcester Road Cemetery, Northampton. Memorial to John Edmund Matthews (died 1928 aged 71), and his wife Elizabeth (died 1951 aged 92).

Such forms of 'rustic', 'naturalistic', boulder or monolith memorial can be found in any decade from the later nineteenth century, but were especially prominent in the period 1870-1940. They may be a reflection of Toplady's popular hymn 'Rock of Ages' which was first published in 1775 but achieved particular regard during and from the terminal illness of Prince Albert in 1861. This is said to be the hymn that has the broadest and firmest grip upon the English-speaking world, and is a comfort in the hour of death. By 1892, the hymn appeared in every hymnbook of merit. ${ }^{18}$ This also coincided with the popularity of rock gardens, constructed to provide alpine plants with surroundings that deliberately imitated nature. ${ }^{19}$ In very recent decades there has been some resurgence of such monolith headstones. While they have never been a dominant memorial form, they are nevertheless frequently found, in town and countryside, with most cemeteries and countless churchyards containing examples. They are present in both Catholic and Protestant areas of cemeteries. They are by

\footnotetext{
18 J. Julian, Dictionary of Hymnology (London, 1892), pp. 970-972. An 1887 survey of 3,500 people rated 'Rock of Ages' as the most popular hymn. I. Bradley, Abide with Me: the World of Victorian Hymns (London, 1997), p. 193.
}

${ }^{19}$ D. Otteweill, The Edwardian Garden (London, 1980), p. 54. 
no means strongly concentrated in Celtic, upland, or granite or slate-quarrying regions, being common for example in Leicestershire and adjoining English midland counties, as well as in Cornwall, the Scottish Highlands or across much of Ireland.

These monolith memorials hint at outlooks or sympathies towards the natural world, conveying notions of the picturesque, notably those of the late Victorian period. Attitudes towards the deep past may also be implicit here. After all, access to Stonehenge and other ancient monuments was a controversial issue, notably from about 1902, and one also thinks of related emblems of Welsh and druidical identity and their changing cultural meanings. Monolith memorials eschew any idea of symmetry or 'perfection', they lack (or contrive to lack) any obvious machine-made quality, and thus in Ruskinian senses they are non-industrial and disposed towards an anti-urbanism, though no doubt industrial processes often contributed to their making. The contrast with carefully carved Gothic memorials, or with the industrially manufactured Art Deco memorials which became common from the mid-1920s and which were specifically extolled as industrial products by the Art Deco Movement - is striking in this respect.

An aspect of irregularity or roughness, even of whimsy, is the hallmark of monolith or boulder forms of rustication. They lack the usual smoothness of Classical memorials. Indeed, some elements of the Gothic are evident in them, as in other forms of rustication: one thinks of the influence of antiquarian ruin imagery; Pugin's liking for natural-looking materials, such as rough stone walling or knapped flint; Ruskin's adapted ideas from Burke of the sublime and of uncorrupted Nature; or Ruskin's stress upon 'sternness and rudeness' and 'imperfection' as aspects of the Gothic. ${ }^{20}$ Ruskin commented upon 'this wildness of thought, and roughness of work; this look of mountain brotherhood between the cathedral and the Alp', as being among the features of Gothic. 'Rather choose rough work than smooth work', he wrote in his famous essay on the nature of Gothic. ${ }^{21}$ Many rusticated memorials take such thinking to extremes. They may also refer us to the post-Darwinian interest in geology. Monoliths are perhaps less obviously Christian than many other types of memorial, though

\footnotetext{
${ }^{20}$ J. Ruskin, The Seven Lamps of Architecture (London, 1849); J. Ruskin, The Elements of Drawing (1857, London, 1991).
}

${ }^{21}$ J. Ruskin, 'The nature of Gothic', in his The Stones of Venice; Vol. 2: The Sea-stories (New York, 2007), p. 167. 
some (e.g. Figure 3) feature a Christian cross or phraseology. One must also be aware of the connotations deriving from St Peter as the rock of the church, or Peter (or Petrus/petra) as meaning rock, and the complex associated theological discussion. ${ }^{22}$

While memorials have their architectural stylistic counterparts, that is much less true of such monoliths. Stark elements of raw landscape are seemingly re-positioned to the sites of burial via these types of memorial. They embody strong traces of naturalism and Romanticism. As with other cases of rustication, they may sometimes refer to aspects of personal character: for one sometimes finds mentions of 'A milestone of progress, work well done'; or of a JP and long-term Mayor of Loughborough; or of 'Service and Courage'.23 Moreover, as can be seen from these illustrations - and a fuller array of images would convey this even more strongly - they are all sculpturally unique in shape, in varying stone type, size and other qualities. In other words, they are distinctive in almost every case, being individual and exceptional as such; they have great variety, and they depart from the regulated predictability of many forms of memorialisation, perhaps most notably during the twentieth century. It appears therefore that they denote memorialised people as unique individuals, rather than as persons apparently (via the frequent clichés of memorialisation) sharing a common religious spirit and emotionality with others from a local or wider community. They pay less regard than many other forms of memorialisation to social, theological or artistic conventions, and this may be one reason for their attraction. These are issues to which we will return.

\section{Other forms of rusticated memorials}

The monolith is a common 'rustic' form, yet only one among many other types. The anchor and rocks motif is widely found, as it had been in eighteenth and nineteenth-century

\footnotetext{
${ }^{22}$ Matthew 16:18; and see https://en.wikipedia.org/wiki/Saint_Peter: 'Names and etymologies', and "Rock" dialogue'. (3.11.2017). See further references there.

${ }^{23}$ Respectively, rusticated memorials for Ernest Hadley, First Medical Superintendent of the City General Hospital, Leicester, 1913-40, died 1947 (Barkby Cemetery, Leics.,); Thomas Mayo, JP and repeatedly Mayor of Loughborough, died 1930 (Loughborough Cemetery); Dr Christopher D. Briggs, no date (Wigston Cemetery, Leics.).
} 
memorial cartouches and other designs. There it had frequently been associated with the theme of Hope and her anchor, often carved on cartouches with a female figure of Hope herself, most notably on slate headstones which could take such detail well. ${ }^{24}$ There are many larger rusticated variants of this form, a common one being a cross set on a rough stony outcrop, with an anchor draped or hung by chains from the cross. This theme involving an anchor fitted well with a rustication memorial, as it was so compatible with rocky depictions, as well as with naval death memorialisation. A rusticated example of the latter from 1915 can be seen in Figure 5.

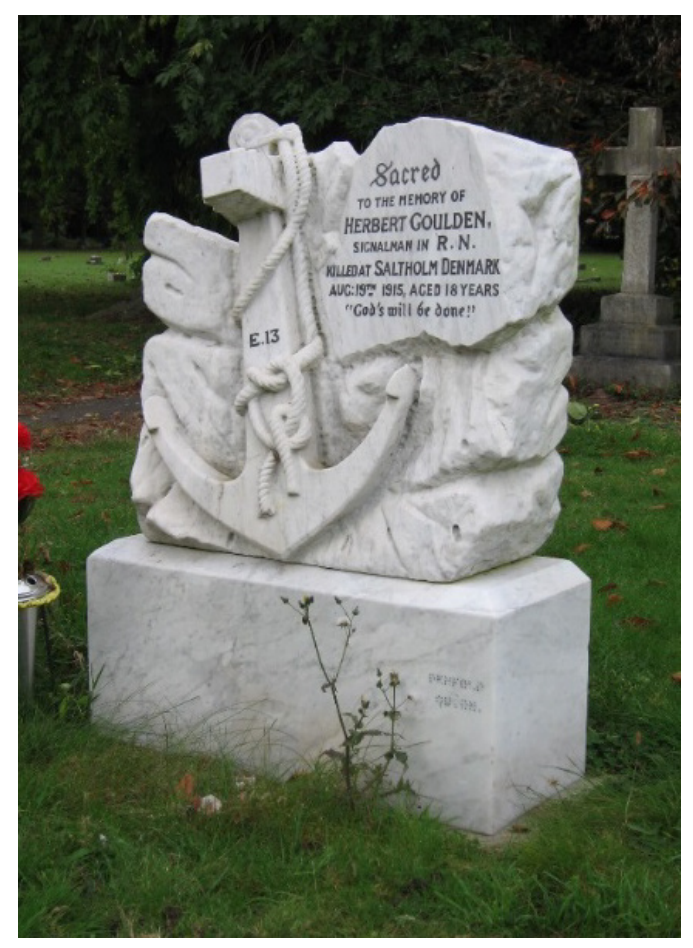

Figure 5. Loughborough Cemetery, Leicestershire. Memorial to Herbert Goulden. Signalman in R.N. Killed at Saltholm, Denmark, 19 Aug. 1915, aged 18 years. “God's will be done".

Another form is the Calvary type of memorial, with a cross set into the top of a rock, which is frequently encountered in many burial grounds, such as Ashwell in Rutland. Another type, of dual rustication, incorporates an angel in rocky or arboreal-cross proximity. An example from a major Victorian cemetery in Leicester is shown in Figure 6.

${ }^{24}$ Burgess, English Churchyard Memorials, pp. 189-90, and fig. 23 (pp. 287 ff). 


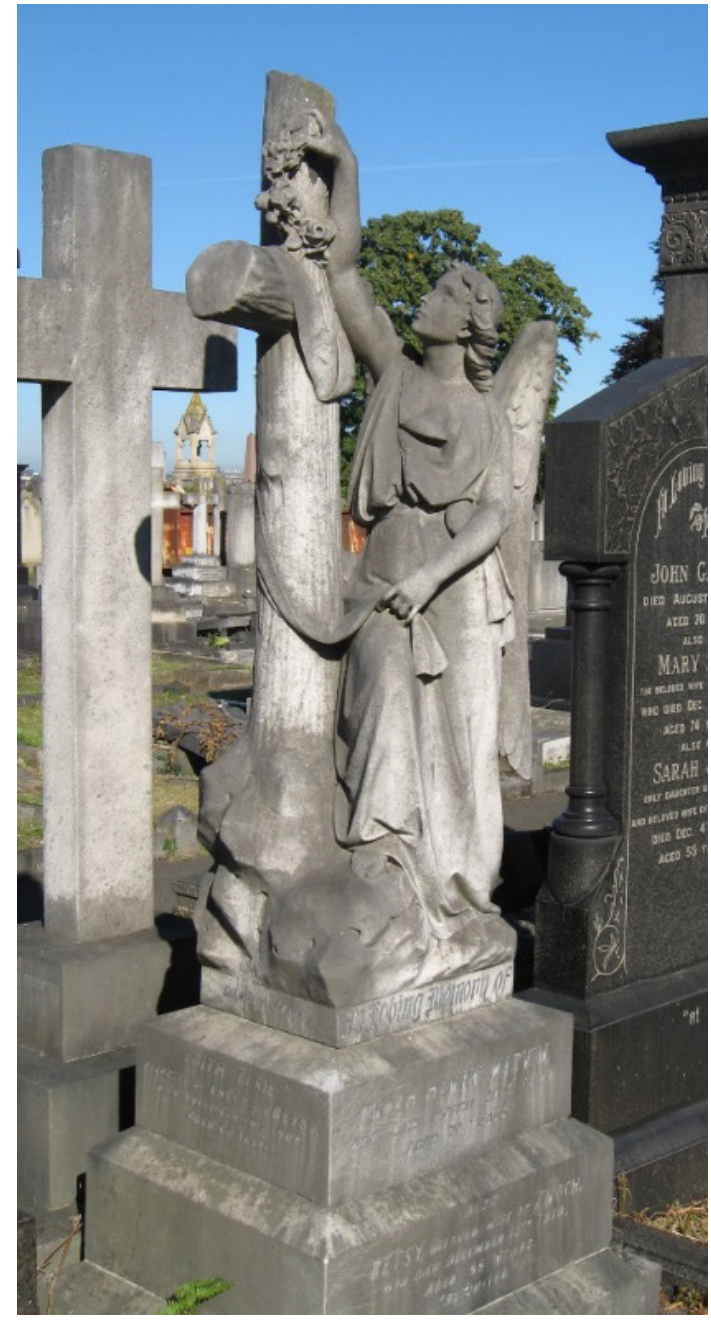

Figure 6. Welford Road Cemetery, Leicester. Memorial to Enoch Henry Marvin (died 1940), and Edith and Betsy Marvin. 


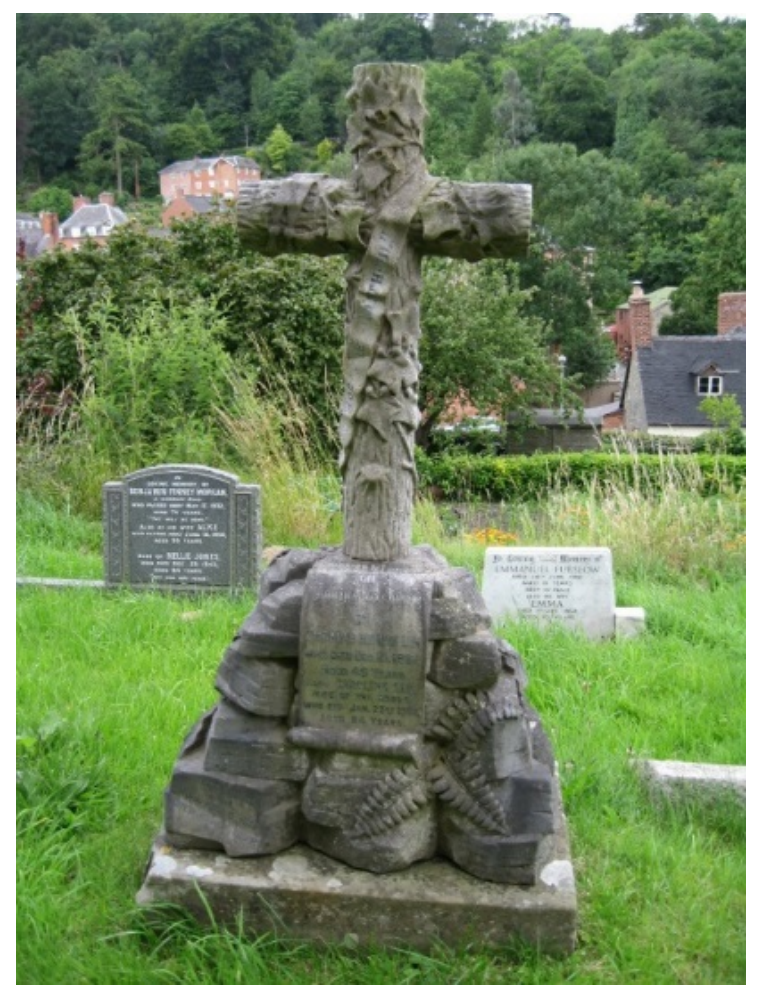

Figure 7. Montgomery churchyard, Montgomeryshire. Memorial to Thomas Henry Lin (died 1892, aged 46), and his wife Caroline Lin.

The treatment of crosses in arboreal fashion is frequent, sometimes adding other kinds of plant growth, and this is often conjoined with rock formations. A dual rusticated example is in Figure 7, from Montgomery churchyard. ${ }^{25}$ This style also featured in a catalogue from 1875 which stated that 'the cardinal principle in designing a gravestone or monument which is to be erected in a Christian burying-place should be to distinctly recognise the Christian faith'. ${ }^{26}$ This recognition is seen repeatedly in the cross, the most meaningful of Christian signs, of course also present in popular hymns such as 'When I survey the Wondrous Cross'. 27

${ }^{25}$ A very similar drawing of dual (rock and wood) rustication is in Burgess, English Churchyard Memorials, p. 127.

${ }^{26}$ Cox and Sons, Illustrated Catalogue of Monuments, Crosses, and Headstones, Tomb Rails, Mural Tablets, Brasses, Bronzes, etc. (n.p., 1875), pp. 1, 15.

${ }^{27}$ W.H. Monk and C. Steggall, Hymns Ancient and Modern (1861, London, 1889), p. 137. 


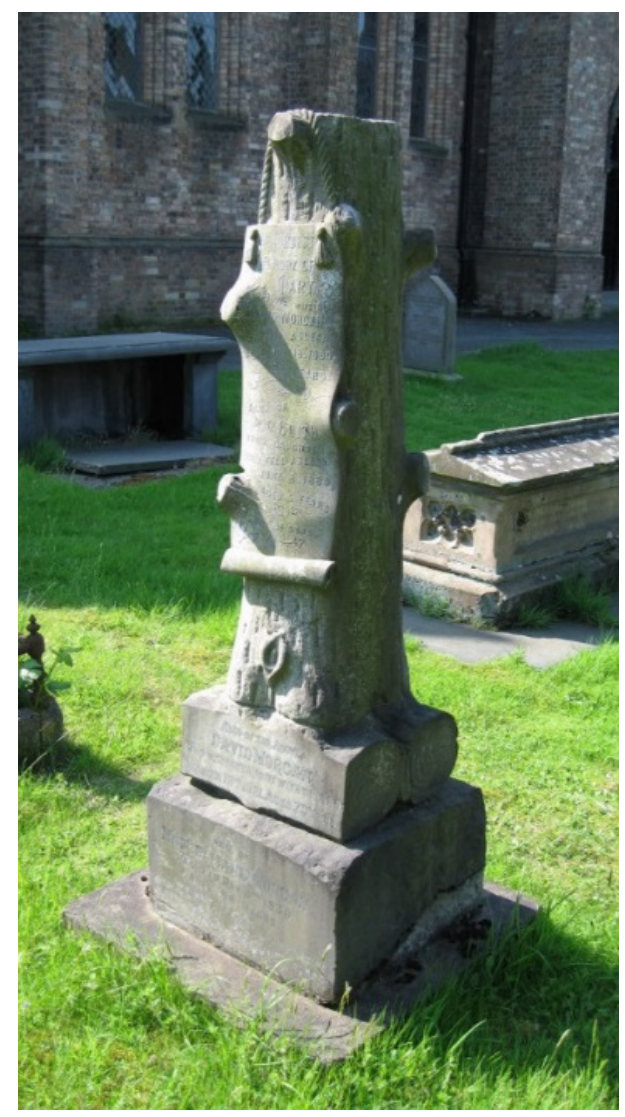

Figure 8. St David's Church, Newtown, Montgomeryshire. Memorial to Mary Morgan (died 1880).

Another form of rustication takes this further to the tree memorial, directly imitating a tree trunk. ${ }^{28}$ See for example Figure 8. In this case, as is often true of Welsh memorials, ${ }^{29}$ the address of the deceased is given, which was 'The Pines', so the design may be a reference to

\footnotetext{
${ }^{28}$ A good example of such a rusticated tree monument (from Irvine, Ayrshire, 1881) is in Willsher, Understanding Scottish Graveyards, pp. 24ff, plate 15.

${ }^{29}$ Wales was a major exception to the arguments about declining place associations on English memorials in K.D.M. Snell, Parish and Belonging: Community, Identity and Welfare in England and Wales, 1700-1950 (Cambridge, 2006), ch. 8. This is rightly, evocatively and bilingually stressed by Stuart Stanton in his filmed observations on Welsh memorials: https: $/ / w w w . y o u t u b e . c o m / w a t c h ? v=H 13 \mathrm{~V}$ kf5qy0\&list=PLLpfS84cDKTF2WPUpvSn6UsgPl3YABpI0\&index=38 (24.1.2018).
} 
this. 'The Pines' also had an orchard. ${ }^{30}$ In other cases one can also find seeming residential linkage, as for example at Llanllwchaiarn churchyard (Montgomeryshire), where a memorial to Dr Dafydd Felix Richards (1924-1968) is shaped like a rock, and Dr Richards lived at 'Rock House'. This type of monument is often found, and indeed in other countries too, sometimes in association with further rusticated features, such as a chair. ${ }^{31}$

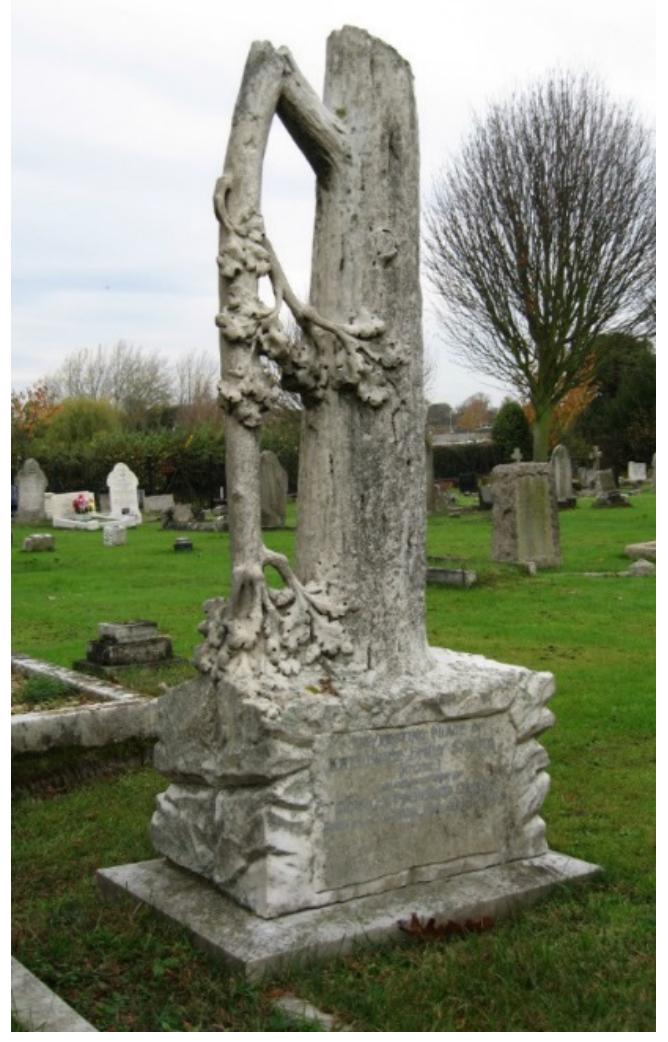

Figure 9. Wolston, Dyers Lane Cemetery, Warwickshire. Memorial to Kathleen Emily Sarah (Kittie) (1886-1919), wife of Charles Frederick Gibbs.

\footnotetext{
${ }^{30}$ Another fine example is at Birmingham Warstone Lane cemetery, being the memorial to Isherwood Sutcliffe (died 1871).

${ }^{31}$ See for example the memorial 'The Empty Chair', Dispersed of Judah Cemetery, New Orleans, Louisiana, USA.

https://www.google.co.uk/search $? q=$ The + Empty + Chair,+ Dispersed $+o f+J u d a h+C e m e t e r y,+$ New + Orleans,, Louisiana, + USA. (4.1.2018).
} 
A further variation of this type is seen in Figure 9, from Wolston (Warwickshire). The lopped tree shown here (as with a broken pillar) refers to a life cut prematurely short, often found on memorial iconography, in this case taking a large-scale and distinctive rustic form. ${ }^{32}$ In some cases rustication contained lettering inscribed onto a rough stone surround and backing, not really amounting to a monolith. Or there could be similar treatment but onto an area surrounded by a rough wooden frame imitated in stone. Another aspect of rustication, which is quite common in the early twentieth century and inter-war period, is what we term the 'rock and scroll' form, of which many variants exist, of quite different sizes. ${ }^{33}$ An example dating from 1918-20 is figure 10, from Tugby churchyard in east Leicestershire. The scroll, featuring on other styles of memorial, reminds us of St Peter at the gates of heaven with his list of names of those to be admitted, and of the book of life mentioned in the New Testament. Here, people named in the book are to be saved on the Day of Judgement. ${ }^{34}$ The hymn, 'When the Roll is Called up Yonder' was written in 1893 and was being used in memorial services by the early twentieth century. ${ }^{35}$

\footnotetext{
${ }^{32}$ On such memorials, see Burgess, English Churchyard Memorials, pp. 184-5.

${ }^{33}$ See the figurative example in Mytum, Recording and Analysing Graveyards, pp. 112-3, n. 8450 in his classification.

${ }^{34}$ King James Bible: Revelations, 20:12.

35 'Salvation Army memorial service', The Times, 25 Sept., 1906.
} 


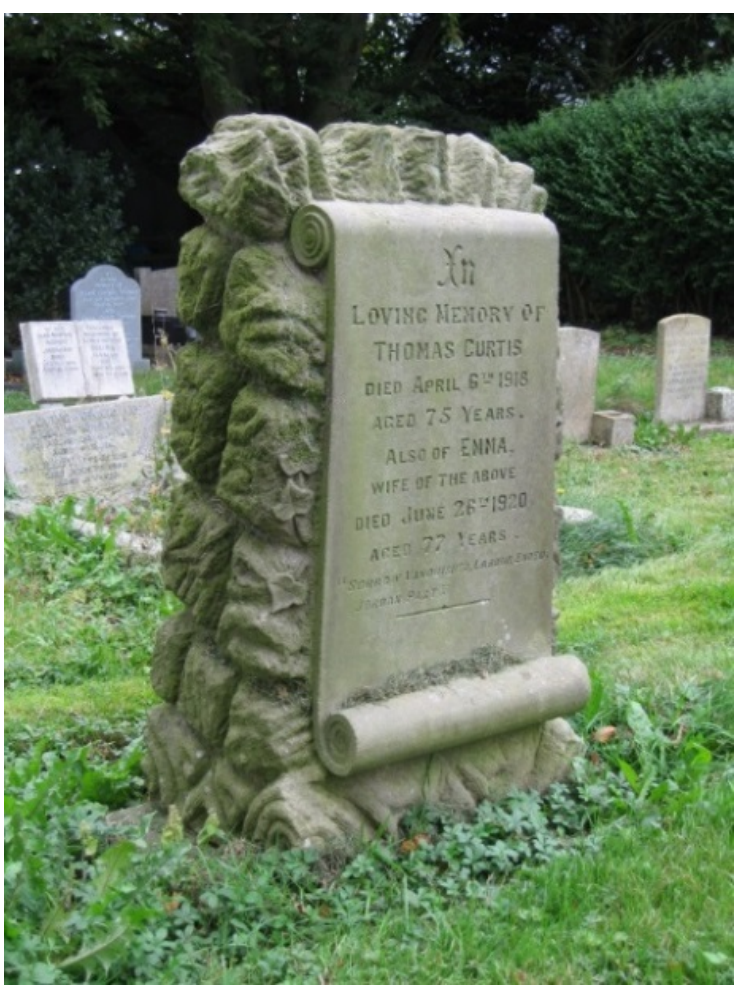

Figure 10. Tugby, Leicestershire. Memorial to Thomas Curtis (died 1918 aged 75), and Emma his wife (died 1920 aged 77).

A very striking form of stone memorial is the rough-timber framed and textured (almost 'log-cabin') type of which many variants exist, in many kinds of stone including marble. ${ }^{36}$ These are sometimes referred to as ' $\log$ pediment'. ${ }^{37}$ An example of this is in Figure 11, from Cottesmore churchyard, Rutland: the memorial to Henry Hollis (1824-1897), and to Hedley his son (1859-1901), 'who served in the R.S.A. police, was at the relief of Mafeking, and died in hospital at Salisbury, South Africa, Feb 28, 1901'.

\footnotetext{
${ }^{36}$ A fine example is at Knighton churchyard (Leicestershire), memorial to Richard Taylor, 1842-1905.

${ }^{37}$ For a figurative example, see Mytum, Recording and Analysing Graveyards, pp. 113-4, n. 8500 .
} 


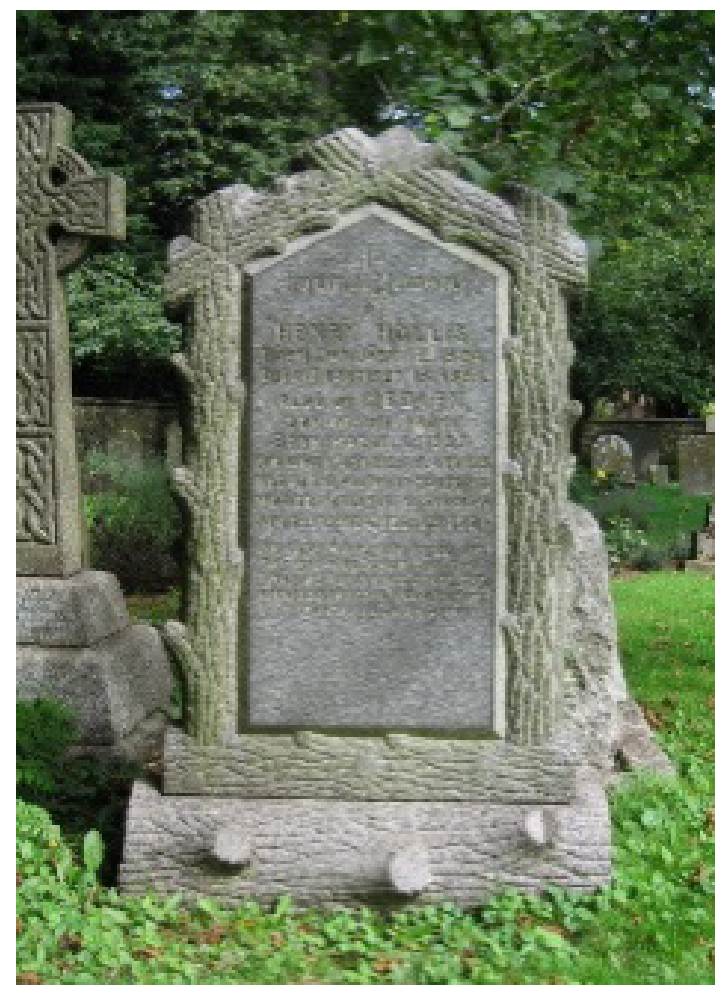

Figure 11. Cottesmore churchyard, Rutland. Memorial to Henry Hollis (1824-1897), and Hedley his son (1859-1901).

These types of rusticated tree rendition had some counterparts in other ecclesiastical forms, such as the elaborate font in a highly rusticated arboreal form at Peatling Parva church in Leicestershire. One might also refer to a long tradition of medieval and post-medieval bench-end carving, which in some less formal styles sometimes adapted elements of tree-like rustication. Such rusticated memorials can be related to many other wood carvings, elements of rustication in church walls and construction, and the like.

\section{Art Nouveau and related rusticated styles}

These forms of rustication were often translated into Art Nouveau and some subsequent memorial styles, such that one might see such developments as separate from 'rusticated', though where there are dominant rusticated elements they warrant inclusion in our definition. As always with memorial styles, they can overlap interestingly. Kensal Green cemetery, for example, features the memorial to George Lenton (died 2004), where swirling water runs through and around rocks. Or it contains the slate outcrop, with broken lyre, which is the memorial to the poet Charles Mackay (1814-1889). A very fine early 1920s memorial to 
Rachel and John Smith in Loughborough cemetery (see Figure 12) comprises Art Nouveau forms coupled with much dual rustication.

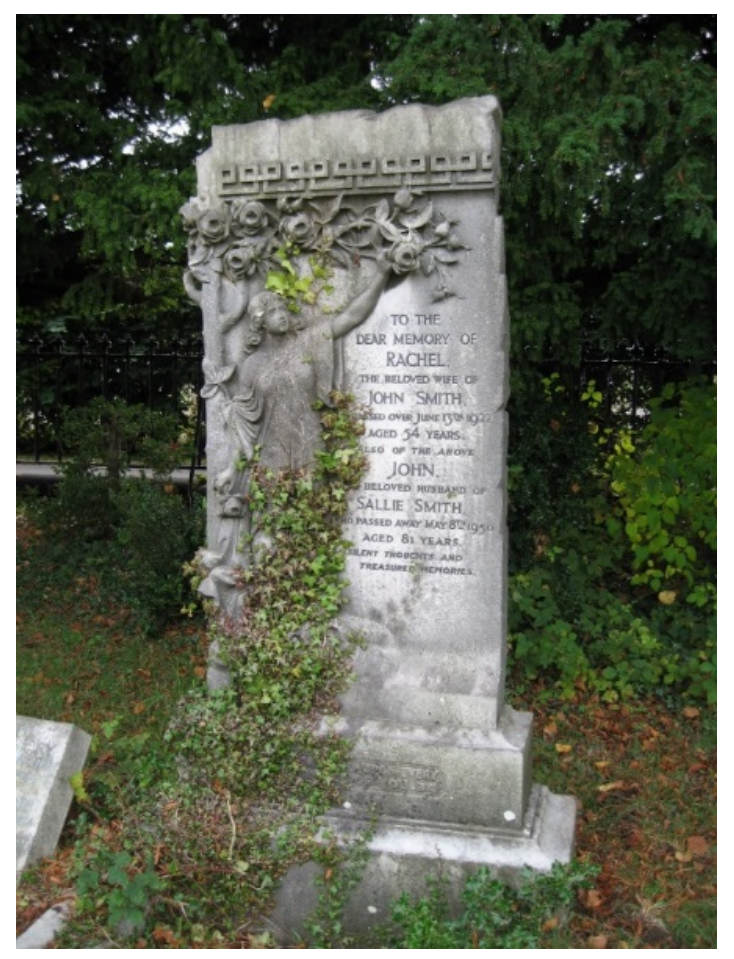

Figure 12. Loughborough Cemetery, Leicestershire. Memorial to Rachel Smith (died 1922) and John Smith.

An even more striking example of this blending of rustication into later styles, in this case into elements of Art Nouveau and Art Deco, is the superb, moving and life-sized memorial, in the same Loughborough cemetery, to Dorothy Bennett (died 1938), shown in Figure 13. 


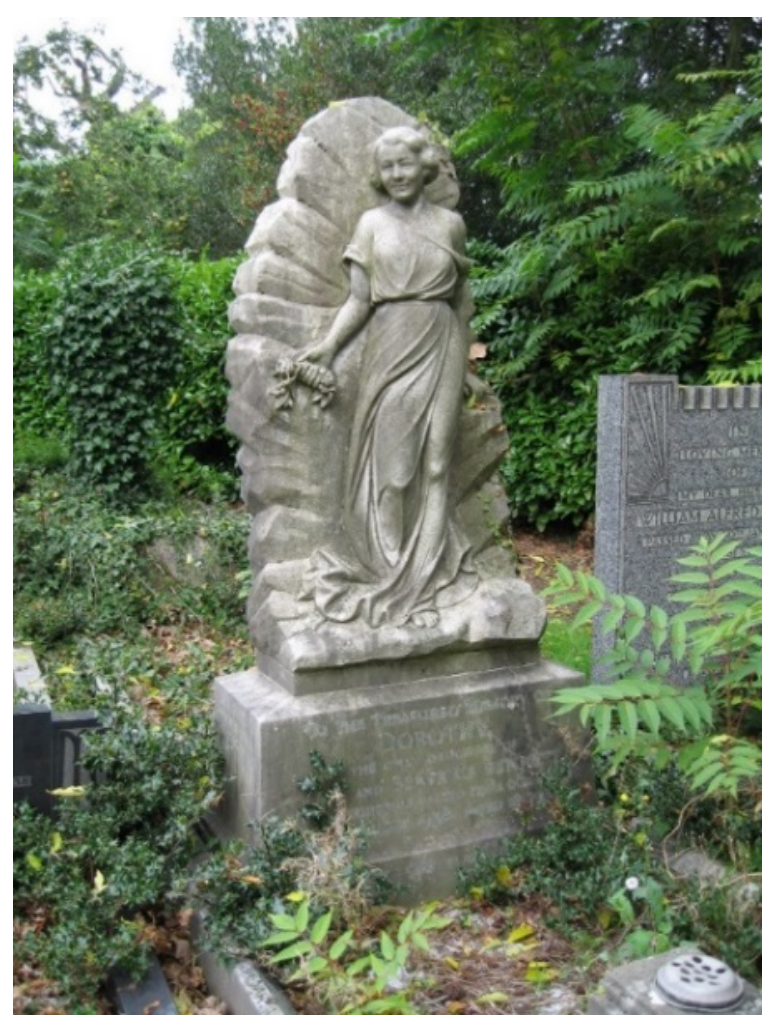

Figure 13. Loughborough Cemetery, Leicestershire. Memorial to Dorothy Bennett (died 1938).

\section{The chronology of change}

Our concern now must be to arrive at a much more precise understanding of the chronology of such rustication, and indeed how it fits with the more common forms of memorial styles: namely those broadly defined as Gothic and Art Deco. Indeed, for all the discussion of 'the Gothic Revival', ${ }^{38}$ the timing regionally and denominationally of that revival is less well specified, and the decline of the Gothic is an even less understood and studied phenomenon. Memorials are a perfect, though as yet non-utilised source, for these issues.

\footnotetext{
${ }^{38}$ For example, among a huge literature, T. Smith, Original Designs for Christian Memorials (Oxford, 1864); K. Clark, The Gothic Revival: an Essay in the History of Taste (1928, London, 1996); C. Brooks, Mortal Remains: the History and Present State of the Victorian and Edwardian Cemetery (Exeter, 1989); M. Aldrich, Gothic Revival (London, 1994); M.J. Lewis, The Gothic Revival (London, 2002); T. Brittain-Catlin, J. De Maever and M. Bressani (eds), Gothic Revival Worldwide: A.W.N. Pugin's Global Influence (Leuven, 2017).
} 


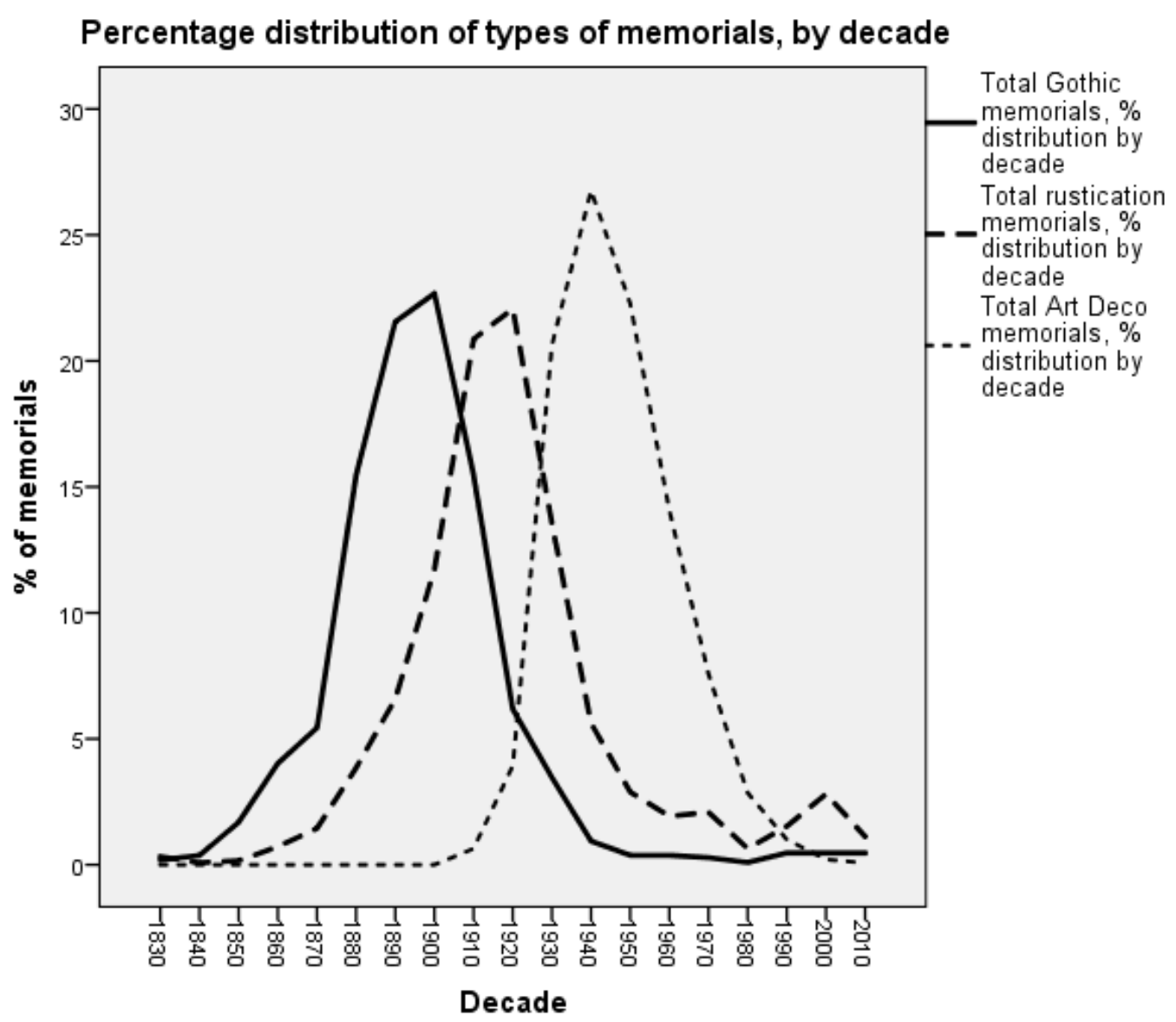

Figure 14. Perentage distribution of types of memorials, by decade.

A total of 165 English and Welsh burial grounds, of all kinds, were studied for this examination of the three styles, and these are listed in our Appendix. Many burial grounds were analysed specifically for one type of memorial, notably the less numerous rusticated ones, while certain burial grounds were analysed for all three types, as is shown in the Appendix. This resulted in comparable distributions for 1,246 rusticated memorials, 1,067 Gothic memorials, and 1,401 Art Deco memorials. These are combined by memorial type for the English east midlands (parishes in Leicestershire, Rutland, Northamptonshire, Lincolnshire, Nottinghamshire and Cambridgeshire), Kensal Green cemetery, and Montgomeryshire (now part of Powys) in the subsequent analysis, for we can detect no significant differences in the respective stylistic chronologies of these English and Welsh churchyard, Nonconformist chapel, and cemetery memorial styles. Nor can we detect any significant dissimilarities in the adoption of rustication in churchyards and cemeteries, despite the undoubted other differences between the cemetery and the churchyard (affecting buildings, respective histories, legal frameworks, clerical control, ritual, or community 
focus). Each separate style appears in the post-c. 1850 period to be synchronous for our regions and largely governed by national tastes.

Figure 14 shows the distribution of surviving memorial types over time, expressed as decadal percentages for that type of memorial. This shows clearly and comparatively the periodicity of each memorial type, while not showing how numerous each type was. Of course, rusticated memorials were relatively small in overall number compared with the dominant Gothic or Art Deco styles (hence the larger number of sites from which they have been sourced), and this is not shown in temporal percentage distributions of each type. This will become clear in two subsequent case studies of Loughborough cemetery and Newtown (Montgomeryshire) cemetery.

A number of points emerge. First, the duration of each style, or memorial fashion, was remarkably similar. Each style in a broad sense lasted about six decades, over different periods, and while rustication shows the greatest duration, lingering more into very recent years, all the styles are extraordinarily co-extensive in longevity to each other. ${ }^{39}$ Second, bearing in mind the relatively minor popularity of rustication as a style, it is remarkable the degree to which Art Deco from the 1920s (and its closest later derivatives) supplanted the Gothic. If the Gothic can be said to characterise a certain kind of Victorian religious sensibility and set of tastes - theological, naturalistic, 'historical' - the supplanting of these by the 'modern' style of Art Deco was dramatic and utterly decisive in the 1920s. An example of an Art Deco memorial (from Loughborough cemetery) can be seen in Figure 15.

\footnotetext{
${ }^{39}$ One is reminded of James Deetz's and Edwin Dethlefsen's 'battleship curve': 'If you were to prepare a graph showing how the designs change in popularity through time, the finished product might look something like three battleships viewed from above, the lower one with the bow showing, the center one in full view, and the third visible only in the stern. This shape, frequently called a "battleship-shaped" curve, is thought by archaeologists to typify the popularity career of any cultural trait across time.' This model of change was apparent from study of the earlier transitions between Death's Head, Cherub, and Urn and Willow styes of memorialisation, from the Stoneham cemetery, north of Boston (Massachusetts), with their respective chronologies. See J. Deetz and E.S. Dethlefsen 'Death's Head, Cherub, Urn and Willow', Natural History, 76: 3 (1967), pp. 29-37, esp. Figure 1; E.S. Dethlefsen, and J. Deetz, 'Death's heads, cherubs and willow trees: experimental archaeology in colonial cemeteries', American Antiquity, 31:4 (1966), pp. 502-10.
} 


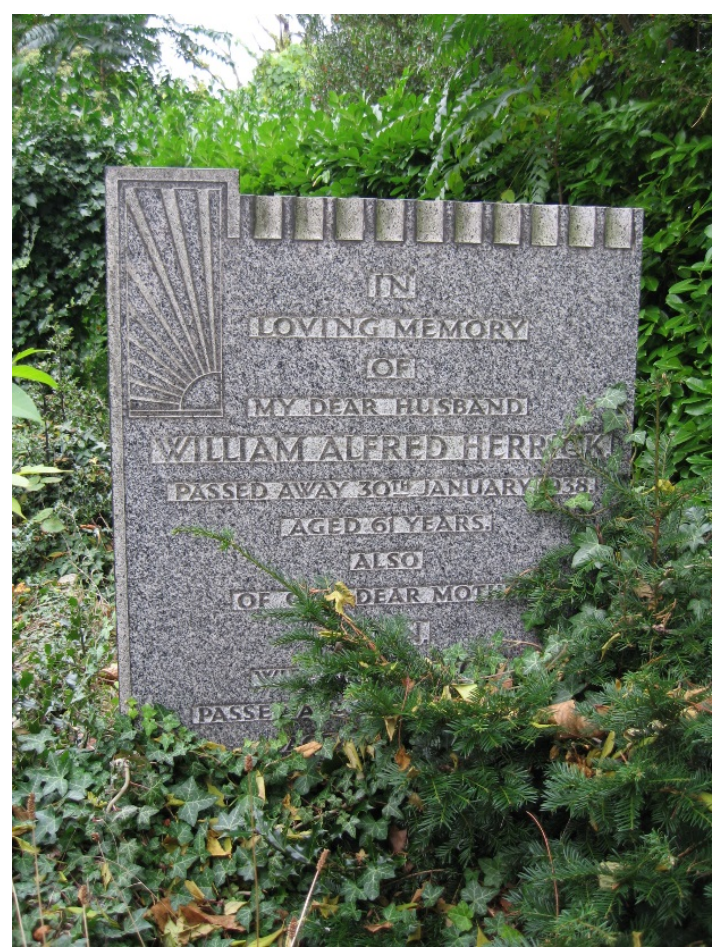

Figure 15. Art Deco memorial, Loughborough cemetery, to William Herrick (died 1938).

This surely has wider ramifications for systems of belief and artistic taste. There was literally, as this chart shows, a cross-over period from one to the other, and that shift was a remarkable and sudden one, seemingly following the influence of the Paris Art Deco Exposition of 1925, and its wide ramifications for architecture and commodity culture. It took advantage of the decline in taste (or the distaste) for the Gothic, and the evident search for more relevant alternatives, that was already apparent by the $1920 \mathrm{~s}$ - for the Gothic memorial had been in marked decline since its heyday in the 1890-1910 decades. The vigorous growth of this Art Deco style after about 1925 is apparent, to peaks in the mid-twentieth century, albeit with steady decline thereafter. ${ }^{40}$

${ }^{40}$ It could perhaps be argued that there is greater continuity of design than is apparent in Figure 14, as many modern memorials bear shifting resemblances to (or echoes of) classic Art Deco styles, in for example rectilinear internal and profile designs; but we have defined 'Art Deco' along the lines of its original 1920s and 1930s manifestations, and not included significantly deviating later styles in the tabulations of Figure 14. For classic Art Deco forms, see T. Menten (ed.), The Art Deco Style, in Household Objects, Architecture, Sculpture, Graphics, Jewelry (New York, 1972); B. Hillier, Art Deco of the 20s and 30s (1968, London, 1972); A. Duncan, Art Deco Complete: the Definitive Guide to the Decorative Arts of the 
Thirdly, and closely related to this, there is what appears to be a generational aspect of change here. What one sees are shifting styles manifesting period and cohort effects, in subjective, artistic and probably secularising trends. Each memorial type, with its respective peaks shown in Figure 14, was clearly and almost equally characterised by a generational span of about sixty years, or rather less if one looks at its main period of popularity. One might presume - though this is complicated by issues of cohort memorial decision making and choice ${ }^{41}$ - that a generation develops fashions that are finally manifest in memorials, and that memorials thus represent something of a time-lagged expression of taste. A peak in Gothic in the 1900s decade, given prevailing life expectancies, thus represents the deaths of countless people who had reached maturity about 30-40 years previously, at the height of Gothic and ecclesiological fashion adoption. Something similar may be manifest in the peaks of the other two memorial types - the rusticated and the Art Deco - though the sweeping nature of fashion change in the twentieth century may have become more rapid than was true in the nineteenth, given advances in post-1870 literacy, the array of media, means of communication and memorial taste transmission.

Finally, and by extension, one notices how the percentage peak of Art Deco exceeds the earlier two styles of memorials. This points to the rapidity and relative compression of this style, compared to the other two styles: it was literally squeezed into a shorter time frame, thus affecting this distributional graphical display in Figure 14. Within the terms of this memorial analysis, such change is not explicable by the rise of cremation, notably from the Cremation Act of 1902 and markedly from the 1950s, ${ }^{42}$ for that rise simply (and

1920s and 1930s (New York, 2009); T. Yorke, Art Deco House Styles (Newbury, Berkshire, 2011); C. Benton, T. Benton, G. Wood (eds), Art Deco, 1910-1939 (London, 2015).

${ }^{41}$ The dead do not bury themselves, though they frequently specify memorial preferences, and thus tastes in memorials also reflect choices of the surviving generation. The extent of these cohort influences upon memorialisation is historically largely unknown. On some classes of the deceased commissioning their own memorials, see N. Penny, Church Monuments in Romantic England (New Haven, Conn., 1977), pp. 17-21.

${ }^{42}$ On the rise of cremation, to about 75 percent of deaths in Britain now, see P. Jupp, From Dust to Ashes: the Replacement of Burial by Cremation in England, 1840-1967 (London, 1990); P. Jupp, 'Cremation or burial? Contemporary choice in city and village', in D. Clark (ed.), The Sociology of Death (Oxford, 1993); T. Crocke (ed.), The Churchyards Handbook 
dramatically) curtailed the numeric scope for burial memorialisation of a traditional kind, rather than truncating a style of burial memorialisation after the Second World War. Again, the pattern here is one of ascribed modernity, or more rapid change in styles, albeit coupled with and supplanted by the rather undistinctive or commonplace nature of neoclassical/Lutyens styles of memorial that have, by and large, taken over from all three of these earlier forms in the modern cemetery or churchyard.

\section{Two cemetery case studies}

It is instructive to develop two regional case studies, comparing Welsh and English situations. Questions arise about 'provincial' or regional differences in the formation of tastes, about often presumed metropolitan diffusion of styles, about Welsh-English comparisons, and the effects of Anglican or Nonconformist dominant cultures. To address such issues, we therefore have chosen Loughborough cemetery in north Leicestershire, and Newtown cemetery (Montgomeryshire, mid Wales, now part of Powys), for this purpose. The results emerge in Figures 16 and 17. We have shown the data in these Figures simply as numerical totals - rather than percentage distributions for each type as in Figure 14 - to convey a sense of relative numbers of each style. The numerical comparison is of course much influenced by the growing incidence (in affordability and in class terms) of stone memorialisation affecting burials in the twentieth century compared with the nineteenth century. A far higher and growing proportion of twentieth-century burials had lasting memorials than was true for the nineteenth century, or respectively for the eighteenth century. ${ }^{43}$ This has some bearing upon the take-up of Art Deco memorialisation, given that this inter-war style was extolled especially as machine-made, 'modern' and 'industrial',

(London, 2001), pp. 56-71; http://www.srgw.info/CremSoc/LegalEtc/Bibliography.html (5.1.2018); http://www.cremation.org.uk/history-of-cremation-in-the-united-kingdom (24.1.2018). Despite an increasing spread of memorialisation for those buried, cremation may have diminished the craft of memorial stonemason, and there was concern about this in the 1950s. See Burgess, English Churchyard Memorials, p. 57.

${ }^{43}$ Unpublished parish-register and churchyard studies (MA students, 'Churchyard Projects', Centre for English Local History, University of Leicester) broadly suggest that about 3-10 percent of churchyard burials in the early nineteenth century have surviving memorials now; the figure for the mid-twentieth century is over 50 percent. 
compared to the somewhat more extensive hand-wrought input to many Gothic memorials thus making Art Deco memorials more price-accessible and facilitating the wider diffusion of memorialisation during the twentieth century. This has of course continued into the largely post-Art Deco era, even though some examples of deliberately 'crude' modern rustication supply exceptions.

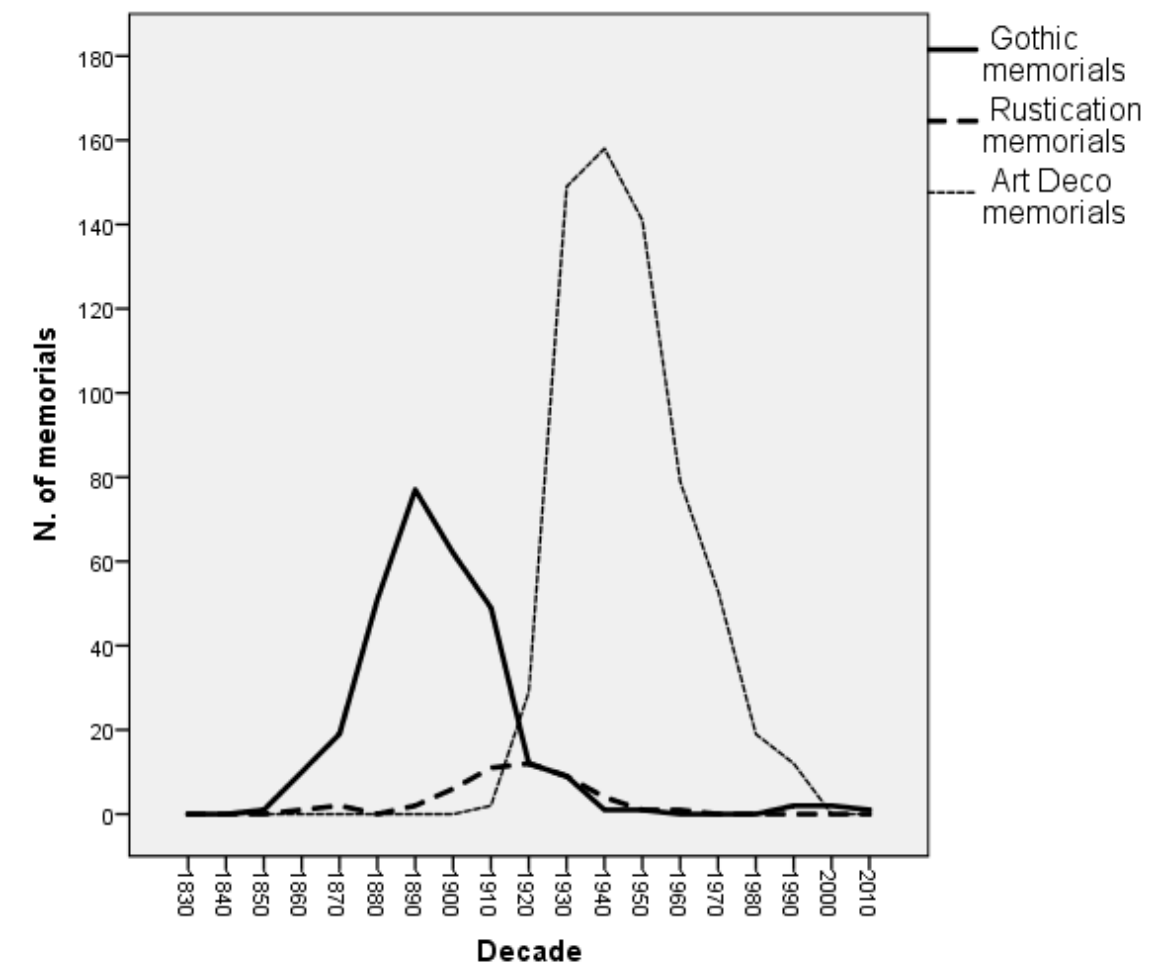

Figure 16. Loughborough Cemetery (Leicestershire): numbers of Gothic, rustication, and Art Deco memorials. 


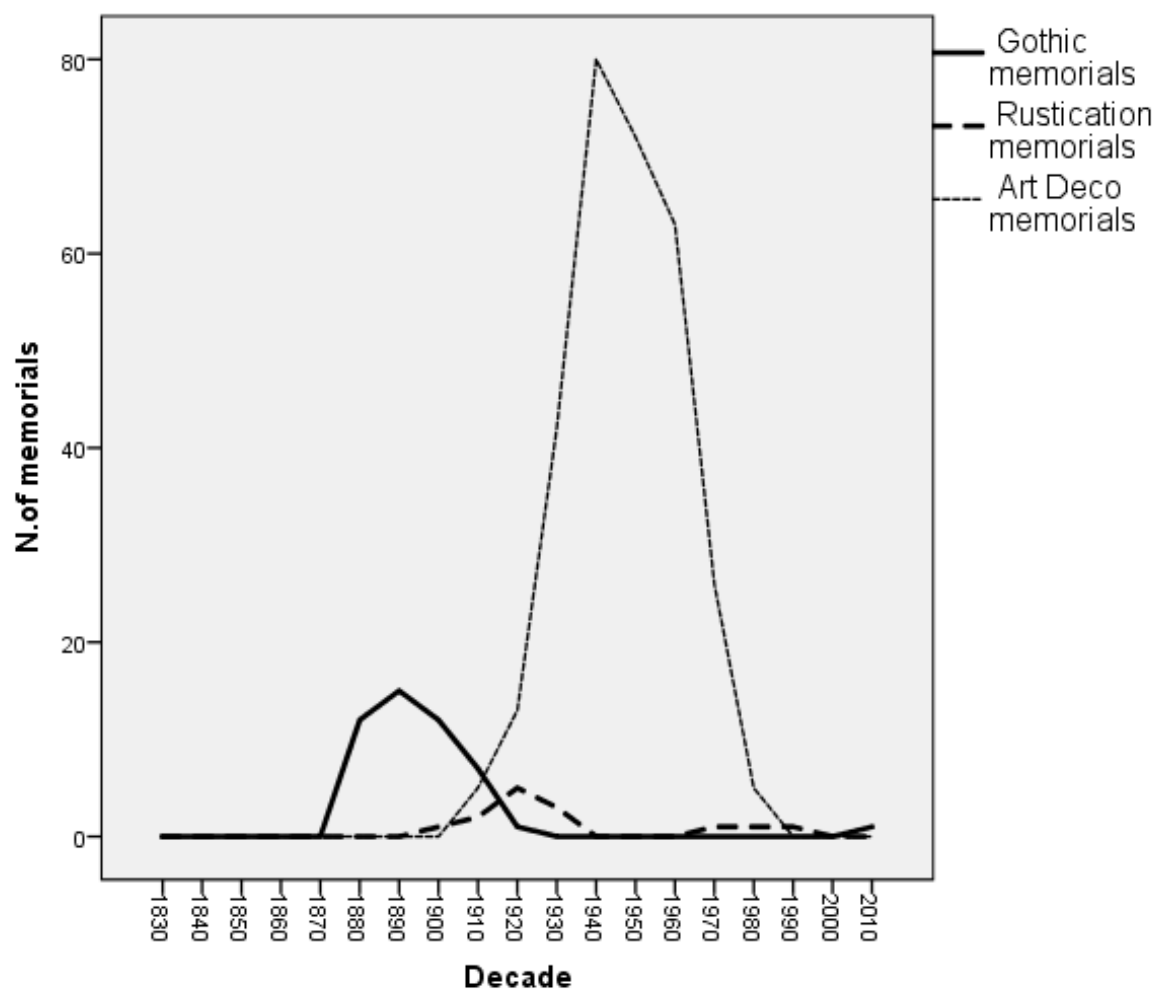

Figure 17. Newtown Cemetery (Montgomeryshire): numbers of Gothic, rustication, and Art Deco memorials.

Loughborough Cemetery was laid out in 1857 and enlarged in 1892 to cover 12.5 acres. ${ }^{44}$ It is still open and occasionally used for burials. The cemetery is designed in picturesque style, surrounded by railings and a dense planting of shrubs and trees. The centrepiece is a Gothic-Revival style chapel building, now used as commercial office space. Two lodges at the front, one in Gothic style, are currently occupied as residential dwellings. ${ }^{45}$ The cemetery also contains about 80 war graves including some of German and Italian servicemen. ${ }^{46}$

The municipal cemetery in Newtown, Montgomeryshire, opened in April 1884. It was constructed because the three nearby churchyards were inadequate for the population of this Welsh textile industrialized town. The cemetery is located on a ten-acre plot, part of a former

\footnotetext{
${ }^{44}$ http://www.genuki.org.uk/big/eng/LEI/Loughborough (4.1.2018).

${ }^{45}$ www.charnwood.gov.uk/pages/loughborough_cemetery_conservation_area (4.1.2018).

${ }^{46}$ Commonwealth War Graves Commission website: https://www.cwgc.org/ (4.1.2018).
} 
racecourse on the eastern edge of the town. This was quite a strongly Nonconformist region, given its Welsh culture. The first interment was of a small child whose burial was overseen by a Wesleyan Methodist minister as the Anglican clergyman would not attend a service and burial in unconsecrated ground. The first monument was erected seven months after the cemetery's opening and was for John Hall (who died in 1882).

In other words, in relation to the chronology of Gothic memorialisation, this Welsh cemetery (like many others) is likely to truncate the early stages of Gothic documentation, which one normally expects to notice by the 1850s. Thus one should not attach too much importance to the steep rise of Gothic shown in Figure 17 for the 1880s. The churchyards that this cemetery replaced show Gothic as a memorial style emerging as early as the 1830s. This is despite the lively Welsh Nonconformity of the area, which might not be expected to conduce to early adoption of Gothic styles. Nevertheless, the peak of Gothic memorials here, in the 1890s, is in line with wider trends, as seen in Figures 14 and 16. There is no evidence of a 'provincial' or Welsh cultural delay behind the spread of Gothic in the English regions. Indeed, the local trends for all three types of memorial match very closely. They even correspond with the rustication trend for the London cemetery of Kensal Green (which peaks 1910-30), a metropolitan venue that one might presume to be forward in fashion. This allows one largely to discard ideas about 'provincial', rural, or Welsh memorial culture lag after the mid-nineteenth century. ${ }^{47}$ The synchronicity here of memorialisation change does not suggest much Celtic backwardness compared to the metropolis or central areas of England, though that remains to be more widely tested for other Celtic countries, and it is worth noting that their religious attendance rates were usually higher than in many English areas at this time. ${ }^{48}$ However, what is perhaps most distinctive in relation to Welsh culture is the precipitous decline in Gothic memorials shown here, somewhat earlier than the twentieth-century prolongation of Gothic style that one sees in the cemeteries or Anglican churchyards of the

\footnotetext{
${ }^{47}$ The evidence for provincial and indeed American lagged adoption of memorial styles in the eighteenth and early nineteenth centuries is much more compelling. Compare for example the chronological arguments in Burgess, English Churchyard Memorials with Deetz, In Small Things Forgotten, and Dethlefsen and Deetz, 'Death's heads, cherubs and willow trees'.

${ }^{48}$ S. Bruce, 'Secularization and church growth in the United Kingdom', Journal of Religion in Europe, 6 (2013), p. 282; S. Bruce, Scottish Gods: Religion in Modern Scotland, 19002012 (Edinburgh, 2014).
} 
English midlands. By the 1920s, in this Welsh cemetery (as indeed in Montgomeryshire generally), Gothic was almost totally abandoned, which was less the case in many English rural and urban burial sites. This must be largely owing to the sceptically anti-Gothic sentiment that was latent in Welsh Nonconformist culture. Many in the Welsh demographic cohorts most strongly expounding such views would of course have been buried in the very early twentieth century, when the sharp decline of Gothic is obvious.

\section{Interpretation and conclusion}

Our greatest stress in this article has been upon rustication, a marginal and neglected memorial type, yet one that has fascinating cultural ramifications and parallels. We have addressed the forms of rustication in relation to other better known memorial styles, throwing light upon their own impact and chronologies. Clearly, major questions arise about generational duration and change in fashions governing memorials, about the Gothic demise - such a neglected theme compared to the Gothic revival - and the cultural implications of the supplanting of Gothic by Art Deco and related 'modern' memorials. Our findings clearly address issues of the rejection of Victoriana, and that may extend to 'eminent Victorians', to ideas of sobriety or decorum, clothing, funeral practices, associations of gloom, and for many people even the churchyard itself. Many 'reforms' in churchyard management of the interwar period appear to be manifestations of that. These issues deserve to be addressed by others. Let us stay in conclusion with this article's main emphasis.

Rustication on memorials was clearly a romantic and picturesque form that peaked between 1890 and 1940, though it shows interesting prolongation through to today. It needs to be associated with the later nineteenth and early twentieth centuries' ideas of the picturesque, the 'back to the land' movement in all its forms, notions about uncorrupted Nature, anti-industrialism and the frequent anti-urbanism of those decades. It probably relates also to the more romanticised or informal ideas of garden design that characterised this period, and which influenced concepts of the churchyard and cemetery. Among those who wished to adopt such forms of memorialisation - and with rustication they were always a small minority - it seemingly spoke to a personalised idea of belonging or ascetic disposition as pertaining to natural or remote or rural places. Improvements in internal transport had made such places more accessible than hitherto to countless people. Rusticated memorials 
were anti-Classical, extolling Nature, natural geology, irregularity, roughness of texture, and in many cases they were anti-symmetrical. The style gave the impression (often an incorrect one) of eschewing industrial processes, notably with monolith memorials, which could be very 'primitive' in inspiration. Its antecedents appear to lie with Burke, Pugin, Darwin, Ruskin, through to a great variety of ruralist and naturalist thinkers of the later nineteenth and early twentieth centuries. There were clearly cultural and chronological parallels to be drawn here with the influences of William Morris and the Arts and Crafts Movement, Edward Carpenter, Octavia Hill, the Guild of Handicraft, and many influential organisations such as the Commons Preservation Society, the National Footpaths Preservation Society, the rambling societies, the National Trust, anti-pollution initiatives, eugenicist impulses, and so on. The influence of popular hymns and well-known biblical references were compatible with some of these inspirations. ${ }^{49}$ The rusticated designs' peak of popularity coincided with many manifestations of the 'back to the land' movement: the agricultural and land colonies; cottage farm settlements; workhouse farms as a social policy initiative; the smallholdings, garden city and allotment movements; or the folksong and dance revival. ${ }^{50} \mathrm{~A}$ large number of rural writers such as Richard Jefferies, Thomas Hardy, W.H. Hudson, John Trevena, Mary Webb, Arthur Machen, Edward Thomas, Gertrude Jekyll, George Sturt, Shelia Kaye-Smith, A.G. Street, Adrian Bell or H.J. Massingham were also influential in extolling or recalling rural motifs, productive agrarian forms and ways of life. Almost all of these writers were anti-urban, often stridently so. ${ }^{51}$ During their lives the British countryside was re-discovered in new ways, and arguably at a more popular level than hitherto. Indeed, many such rural motifs persisted on other (far more numerous) memorials which have not been considered in

${ }^{49}$ Ian Bradley comments: 'in view of their enormous influence and impact, it is surprising that little attention has been paid to hymns by those writing about Victorian Britain.' I. Bradley, Abide With Me: the World of Victorian Hymns (London, 2011), p. xvii.

${ }^{50}$ G. Boyes, The Imagined Village: Culture, Ideology and the English Folk Revival (Manchester, 1993); E. Howard, Garden Cities of Tomorrow (London, 1902); S. Buder, Visionaries and Planners: the Garden City Movement and the Modern Community (Oxford, 1990); J. Burchardt, The Allotment Movement in England, 1793-1873 (Woodbridge, 2002).

${ }^{51}$ For such anti-urbanism in Thomas Hardy, James Wentworth Day, Adrian Bell and H.E. Bates, see respective chapters in K.D.M. Snell, Spirits of Community: English Senses of Belonging and Loss, 1750-2000 (London, 2016). The best overall discussion is G. Cavaliero, The Rural Tradition in the English Novel, 1900-1939 (London, 1977). 
our discussion, which were genre continuities from earlier eighteenth-century traditions of rococo and complex flower motifs, as indeed from some elements of Gothic design and related Nature symbolism. How did such symbols help people mourn, how were their associations helpful, and how did they change? The memorial study of such selective enduring symbols into a more secular worldview is, as yet, a largely undeveloped field of study.

The frequently absent elements of religious memorialisation that can accompany rustication, especially in its most extreme monolith forms, appear to bear testimony to the growing secularisation of thought over this period, ${ }^{52}$ even though many rusticated memorials still embodied religious and devotional symbolism and epitaphs. Nature, on such memorials, was itself often a quasi-religious way of thinking, as it was in writers such as Richard Jefferies or Edward Thomas. As Jan Marsh wrote: 'love of Nature...enabled many late Victorians to dispense with God gradually, as it were'. ${ }^{53}$ The decline of the Gothic, and the rise of Art Deco (to focus on the major trends in memorialisation), also clearly pertain to this line of thinking, even though Art Deco memorials and the rectilinear modernism that they embodied could also sometimes contain religious symbolism such as the sign of the cross. The greatest significance and subjective appeal of memorial rustication probably lay here: in its apparently Nature betokening, incipient secularising, and individualising quality. These memorials were a very distinctive personal choice when set against Gothic normalcy. Increasing individualism is often held, in secularisation theory, to be one of the

\footnotetext{
${ }^{52}$ On 'secularisation', see O. Chadwick, The Secularization of the European Mind in the Nineteenth Century (Cambridge, 1990); K.D.M. Snell and P.S. Ell, Rival Jerusalems: the Geography of Victorian Religion (Cambridge, 2000), ch. 12; A.C. Crockett, A Secularising Geography? Patterns and Processes of Religious Change in England and Wales, 1676-1851 (unpub. Ph.D. thesis, University of Leicester, 1998); C.G. Brown, The Death of Christian Britain: Understanding Secularisation, 1800-2000 (London, 2001); D. Voas and A. Crockett, 'Religion in Britain: neither belonging nor believing', Sociology, 39 (2005); S. Bruce, Secularization (Oxford, 2011); L. Woodhead and R. Catto (eds), Religion and Change in Modern Britain (Abingdon, 2012); Bruce, 'Secularization and church growth'; B. Clements, Religion and Public Opinion in Britain: Continuity and Change (Basingstoke, 2015); A. Berg-Sørensen (ed.), Contesting Secularism: Comparative Perspectives (2013, Abingdon, 2016), esp. pp. 137-62.

${ }^{53}$ Marsh, Back to the Land, p. 35.
} 
manifestations or causes of secularisation, ${ }^{54}$ alongside factors such as social diversification and pluralism, the growth of technological options to religious solutions, and changes within the history of ideas. Rustication bore witness to a growing emphasis on individualistic choice and substitution of 'natural' symbols for Victorian religion and Gothic truisms, hitherto collectively shared even across denominations amid the memorial-leaving classes. One way of reading this is to see it as a step towards more recent modern 'natural burial' practices, for in principle some of the monolith-type memorials proximate to the principles behind that. Indeed, one could go further and suggest that rustication also shared something with the individualised concept and 'freedom' of scattering ashes elsewhere associated with the growth of cremation. ${ }^{55}$ One thinks for example of Arthur Wainwright's ashes scattered on some bleak Lake District path near Windermere: for him an apposite and lonely sign, an extension of personality, linking himself to monolith-like structures, and incidentally rejecting in death any association with a community or even family of settled people. And he has not of course been alone in such a gesture, as any climber of Snowdonia knows.

The frequent irregularity and distinctiveness of rustication (albeit not true of all such memorials) may suggest some break with memorial traditions which extolled similarity and shared purpose with others in 'the community'. Compared for example to the classicism of many earlier memorials, or the Gothic forms most associated with the Victorian period, and many other 'expected' or predictable period orthodoxies, there is rather less scope to see the more highly individualised rusticated memorials as enhancing 'a community of the living and the dead', in Wordsworth's phrase. ${ }^{56}$ Furthermore, rustication may also have occasionally hinted at populist rather than community-wide sympathies, following some earlier socioarchitectural associations of rustication, in what was now an increasingly class divided society.

${ }^{54}$ For example, see Bruce, ‘Secularization and church growth', p. 274.

55 'The scattering of cremated remains is the ultimate symbol of freedom and independence, both from kin, kind and locality'. P. Jupp, 'Cremation or burial? Contemporary choice in city and village', in D. Clark (ed.), The Sociology of Death: Theory, Culture and Practice (Oxford, 1993), p. 184.

${ }^{56} \mathrm{~W}$. Wordsworth, 'Essay upon Epitaphs, in W.J.B. Owen and J.W. Smyser (eds), The Prose Works of William Wordsworth, 3 vols (Oxford, 1974), vol. 2, p. 56. 
Such rusticated memorials remind one of the thoughts of Thomas Hardy when he extolled the 'unspoilt' rural as the basis for true individuality. ${ }^{57}$ They were a minority transition point between the increasingly abandoned clichés and socio-liturgical associations of costly Victorian Gothic - with their communitarian theologies, Puginesque 'medievalism' and senses of religious purpose - and the much more secular, accessible, machine-age world of Art Deco and its subsequent memorial derivatives. Those post-1925 dominant memorial styles, through to the present, were arguably less artistically individualistic than rustication, and in their industrial rectilinear forms they parted company radically from the Nature gesturing of rustication. Yet their ultimate significance of course lay in the fact that they finally allowed so many more people to be memorialised with any degree of permanence at all - which was itself a widening form of individualistic expression and recognition.

\section{Appendix: Churchyards and cemeteries analysed}

All midland burial sites are in Leicestershire or Rutland unless otherwise mentioned. All are Anglican churchyards unless otherwise specified. All data were analysed using SPSS.

Rustication memorials were from Kensal Green cemetery (London), and in the English midlands were from the following churchyards and cemeteries:

Allexton,

Arnesby,

Ashwell,

Barkby cemetery,

Barkby,

Barrow on Soar cemetery,

Bassingthorpe (Lincs),

${ }^{57}$ T. Hardy, 1912 Preface to Far From the Madding Crowd (1874, London, 1974), pp. 38-9; T. Hardy, 'The Dorsetshire labourer', in J. Moynahan (ed.), The Portable Thomas Hardy (1977, Harmondsworth, 1979), pp. 716-7, 725, 734. 
Belton in Rutland,

Billesdon cemetery,

Billesdon,

Bisbrooke,

Bitchfield (Lincs),

Blaston,

Braceborough (Lincs),

Braunston in Rutland,

Braunston, Evington,

Bringhurst,

Broughton Astley cemetery,

Broughton Astley,

Broughton cemetery (N'Hants),

Burton le Coggles (Lincs),

Burton Overy,

Carlby (Lincs),

Carlton Curlieu,

Castle Bytham (Lincs),

Church Langton,

Clipston,

Copt Oak,

Corby Glen (Lincs),

Corby, Old cemetery (N'Hants),

Cosby,

Cottesmore,

Countesthorpe cemetery,

East Farndon (N'Hants),

East Norton,

Edenham (Lincs),

Empingham,

Exton,

Frolesworth,

Gilmorton,

Great Cransley cemetery (N'Hants), 
Great Oxendon (N'Hants),

Greatford (Lincs),

Greetham,

Gumley,

Gunby (Lincs),

Hacconby (Lincs),

Horninghold,

Houghton on the Hill,

Husbands Bosworth cemetery,

Kelmarsh (N'Hants),

Kibworth Harcourt cemetery,

Kibworth Harcourt,

Kilby,

Kirby Muxloe cemetery,

Kirby Muxloe,

Knighton,

Knossington,

Lamport (N'Hants),

Leicester Welford Road cemetery,

Loddington,

Loughborough cemetery,

Market Harborough cemetery,

Marston Trussell (N'Hants),

Medbourne,

Melton Mowbray cemetery,

Morton (Lincs),

Mountsorrel cemetery,

North Witham (Lincs),

Northampton cemetery, Billing Road (N'Hants),

Northampton cemetery, Kingsthorpe Road (N'Hants),

Northampton cemetery, Towcester Road (N'Hants),

Nottingham Church cemetery, Mansfield Road (Notts),

Nottingham Southern cemetery (Notts),

Oakham cemetery, 
Peatling Parva,

Peterborough Broadway cemetery (Cambs),

Peterborough Eastfield cemetery (Cambs),

Pilton,

Quorn cemetery,

Quorn,

Rothley cemetery,

Sapcote,

Sharnford,

Sibbertoft,

Skeffington cemetery,

Skillington (Lincs),

Slawston,

Stainby (Lincs),

Stoke Rochford (Lincs),

Stoney Stanton,

Stoughton,

Sutton in Elms Baptist chapel,

Swayfield (Lincs),

Theddingworth Congregational chapel,

Theddingworth,

Thrussington,

Thurcaston and Cropston cemetery,

Thurlby (Lincs),

Tilton on the Hill,

Tugby,

Tur Langton,

Uppingham cemetery,

Uppingham,

Wardley,

Welham,

Weston by Welland,

Whissendine,

Whitwick Roman Catholic church, 
Wigston cemetery,

Wilsthorpe (Lincs),

Wing,

Witham on the Hill (Lincs),

Woodhouse Eaves,

Woodhouse.

Gothic memorials for the English midlands were from the following churchyards and cemeteries:

Allexton,

Bassingthorpe (Lincs),

Bisbrooke,

Bitchfield (Lincs),

Braceborough (Lincs),

Broughton (N'Hants),

Broughton Astley cemetery,

Broughton Astley,

Broughton cemetery (N'Hants),

Burton le Coggles (Lincs),

Carlby (Lincs),

Castle Bytham (Lincs),

Clipston,

Corby Glen (Lincs),

East Farndon (N'Hants),

Empingham,

Exton,

Frolesworth,

Great Cransley (N'Hants),

Great Cransley cemetery (N'Hants),

Great Oxendon (N'Hants),

Greatford (Lincs),

Gumley,

Gunby (Lincs), 
Horninghold, Knighton,

Kelmarsh (N'Hants),

Kibworth Harcourt,

Knossington,

Lamport (N'Hants),

Leicester cathedral,

Loddington (N'Hants),

Loughborough cemetery,

Marston Trussell (N'Hants),

Medbourne,

North Witham (Lincs),

Old (N'Hants),

Orton (N'Hants),

Pilton,

Sapcote cemetery,

Sapcote,

Seaton,

Sharnford,

Skillington (Lincs),

Stainby (Lincs),

Stoke Dry,

Stoke Rochford (Lincs),

Stoney Stanton,

Stoughton,

Sutton in Elms Baptist chapel,

Swayfield (Lincs),

Thurlby (Lincs),

Uppingham,

Walgrave (N'Hants),

Weston by Welland,

Wilsthorpe (Lincs).

Art Deco memorials for the English midlands were from the following churchyards and cemeteries: 
Billesdon cemetery,

Copt Oak,

Gaulby,

Hallaton cemetery,

Horninghold,

Kings Norton,

Knighton,

Loughborough cemetery,

Mountsorrel cemetery,

Quorn,

Stoke Dry,

Uppingham cemetery,

Uppingham.

Rustication memorials in Montgomeryshire were from the following churchyards and cemeteries. All Welsh burial sites are Anglican/Church in Wales unless otherwise specified.

Aberhafesp,

Berriew cemetery,

Bettws Cadewain,

Carno,

Guilsfield cemetery,

Guilsfield,

Kerry cemetery,

Kerry,

Leighton,

Llandinam,

Llanfair Caereinion cemetery,

Llanfair Caereinion,

Llanfyllin cemetery,

Llanidloes cemetery,

Llanidloes,

Llanllwchaiarn,

Llansantffraid cemetery, 
Llansantffraid,

Llanwnog,

Machynlleth cemetery,

Machynlleth,

Montgomery,

Newtown cemetery,

Newtown St. David's,

Trefeglwys cemetery,

Trefeglwys,

Welshpool cemetery,

Welshpool St Mary's.

Gothic memorials in Montgomeryshire were from:
Aberhafesp,
Berriew cemetery,
Berriew,
Bettws Cedewain,
Buttington,

Kerry cemetery,

Kerry,

Leighton,

Llanidloes cemetery,

Llanidloes,

Llanllwchaiarn,

Llanmerewig,

Llanwnog,

Newtown cemetery,

Newtown Wesleyan chapel,

Newtown, St David's,

Newtown, St Mary's,

Rhydfelin Baptist chapel,

Trefeglwys cemetery,

Trefeglwys. 
Art Deco memorials in Montgomeryshire were from:

Newtown cemetery. 